\title{
ГЕОДЕЗІЯ
}

\section{UDK 528.481}

\author{
K. TRETYAK ${ }^{1}$, F. K. F. AL-ALUSI ${ }^{2}$, L. BABIY ${ }^{3}$ \\ ${ }^{1}$ Department of high geodesy and astronomy, Lviv Polytechnic National University, 12, S. Bandera Str., Lviv, Ukraine, \\ 79013 \\ ${ }^{2}$ Educational and scientific laboratory "Processing of satellite measurements", Lviv Polytechnic National University, 12 , \\ S. Bandera Str., Lviv, Ukraine, 79013 \\ ${ }^{3}$ Department of photogrammetry and geoinformatics, Lviv Polytechnic National University, 12, S. Bandera Str., Lviv, \\ Ukraine, 79013
}

\section{INVESTIGATION OF THE INTER-RELATIONSHIP BETWEEN CHANGES AND REDISTRIBUTION OF THE ANGULAR MOMENTUM OF THE EARTH, THE ANTARCTIC TECTONIC PLATE, THE ATMOSPHERE, AND THE OCEAN}

https://doi.org/10.23939/jgd2018.01.005

Purpose. The purpose of this work is elaboration of the results of long-term GNSS-observations at permanent stations located on the Antarctic tectonic plate; the determination of the change in its rotational parameters and angular momentum, the calculation of the angular momentum of the Earth, the oceanic and atmospheric masses, and the establishment of the interrelationship between these parameters. Methods. The work represents an improved algorithm for determining the parameters of the Euler pole and the angular velocity of the tectonic plate, taking into account the continuity and unevenness of time series of daily solutions of the spatial location of permanent GNSS-stations. Results. According to the results of daily solutions of 28 permanent GNSS-stations in Antarctica for the period (1996-2014), the average position of Euler pole, the angular velocity of the plate, and their annual changes are determined. The annual parameters of the tensor of inertia and angular momentum of the Antarctic tectonic plate are determined. Using the data of the Earth's rotation service and geophysical observations, the annual changes in the angular momentum of the Earth, the tensors of moment of inertia, and angular momentum of oceanic and atmospheric masses for the period (1996-2014) have been calculated. Scientific novelty. It is established that during the whole observation period the increase of the angular momentum of the Antarctic tectonic plate corresponds to the decrease of the angular momentum of the Earth and the atmosphere. This indicates the conservation of angular momentum. The increases of the angular momentum of Antarctic tectonic plate corresponds to the increases of the angular momentum of the ocean. Explanation of this interrelationship requires additional research.

Key words: Antarctic plate; angular momentum; tensor of inertia; angular velocity; Euler pole; GNSSstations.

\section{Introduction}

It is known that Earth's rotation irregularities are affecting the uniformity of scale UT (Universal Time). The unevenness of the Earth's rotation is determined by the change in angular velocity and displacement of the position of the rotation axis relative to the solid Earth (the motion of the pole).

Variations of angular speed are of three types: 1) periodic or quasiperiodic, 2) secular, and 3) irregular. The reason for periodic change of the velocity of the Earth's rotation is the Earth's tides caused by gravity of the Sun and the Moon. The force of attraction of the Earth by the Sun and the Moon forms tides in the crust and the oceans, as well as periodic and secular changes in the length of day (LOD). The secular effect of tidal friction in the body of the Earth and the oceans lead to a slow decrease in the angular velocity of the Earth's rotation. The secular slowing down of the Earth's rotation velocity is the reason for the motion of tectonic plates, which occur on the basis of the conservation of angular momentum of all geospheres: nucleus, mantle, tectonic plates, atmosphere, and the ocean, and the displacement of the coordinates of the Earth's center of masses [Xiaoping Wua, Jim Ray, Tonie van Dam, 2012]. Based on the analysis of inertial motion of the asthenosphere and solid upper layers of the Earth, it is assumed that each particle of mantle substrate tries to conserve its angular momentum with the changing velocity of the Earth's rotation [Fylatj'ev, 2007]. Theoretical studies argue that the rotating motion of the tectonic block according to the law of conservation of angular momentum leads to the generation of deformations and stresses in surrounding 
blocks [Vikulin, 2015a] [Vikulin et al., 2016]. Therefore the resulting field of tectonic stresses of all blocks, plates, and geological structures of the Earth is a manifestation of their interaction within the framework of a rotational model of the Earth. It is established that the changes of LOD lead to horizontal shear stresses acting on the crust with a pressure up to 0.4 MPa [Doglion, 2015]. In essence, this stress-strain state in conjunction with the uneven rotating motion of the Earth is a dominant factor on the impact on Earth's geodynamic processes and their manifestation in seismic and volcanic activity. Similar conclusions are obtained on the basis of paleotectonic studies, which confirm the law of conservation of angular momentum in the global system of tectonic plates. According to paleomagnetic and paleotectonic studies, it has been proven that changes in the rotational motion of the Earth about 46 million years ago led to changes in the angular velocity of the Pacific plate, and changes in its direction of motion from the north to the west. Accordingly, the Australian plate has restored its subduction under the island arc of Indonesia, which continues up to this time. Thus, the model of the interaction of these plates is a consequence of the tectonic conservation of angular momentum.

On the basis of paleomagnetic and paleotectonic studies it was established that conservation of angular momentum of tectonic plates explained at the planetary scale not only slow rotational deformations of the neighbouring tectonic plates, but also cause abnormal displacement of tectonic plates caused by powerful blows of asteroids, which have manifested in the terrestrial relief and folded dislocations of the Earth's crust.

The consequence of the axial rotation of the Earth is also the manifestation of the Coriolis forces, causing the backlog of continental lithospheric plates from the rotation of the mantle substrate of the planet directed from the west to the east and, and as a conesquence, their relative displacement is to the west. This Coriolis force is responsible for the asymmetry of mid-ocean ridges in the meridional direction [Khain, 2010]. The same changes are manifested in the kinematics of atmospheric and oceanic masses and climate change. One example of long-period changes in the Earth's axis tilt and angular velocity change is Milankovitch cycles that were used to explain the alternation of glacial and interglacial periods.

Periodic tidal forces act directly on the gravitational field of the Earth and deform its shape. Correspondingly, changes in the angular velocity of the Earth lead to redistribution of the angular momentum between the arth's crust, hydrosphere, and atmosphere.
Appearance of stresses between the Earth's core and the mantle, and violations of isostatic and postglacial equilibrium, can also be a trigger for the release of accumulated energy in the Earth's crust and the excitement of seismic and volcanic activity [Sottili, 2015]. LOD change correlates with the amount of earthquakes and seismic energy that is released as a result of its action (Fig. 1) [Martin, 1972)].

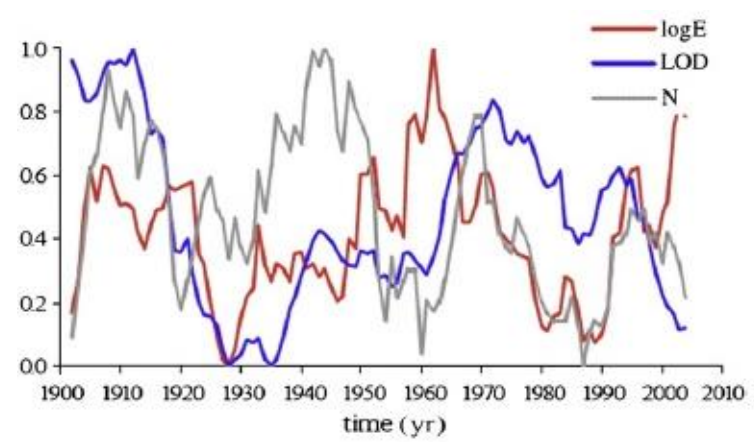

Fig. 1. Dependence of the number of earthquakes $\boldsymbol{N}$ and their energy $\boldsymbol{E}$ on the change of the LOD duration

The increases of the LOD causes the appearance of more earthquakes and growth of released energy. However, it is possible to also inverse the effect of the manifestation of irregular spin-off changes of the LOD due to the effects of strong earthquakes, volcanic eruptions, and actions beyond the planetary phenomena (emissions of the plasma of the Sun) [Pandul, 2010].

Taking into account the importance of considering the rotational factors in the study of motions of geological and geophysical environments [Khayn, 2007] it should be noted that changes in the rotation of the Earth should have a different effect on geodynamic processes of the tectonic plates depending on their geographical location. In this aspect, an Antarctic tectonic plate is special. This is the only plate within which there is its Euler pole, around which its rotational motion is performed, and the Earth's axis of rotation passes through it. It is one of the largest tectonic plates of the Earth, and its area is more than $11 \%$ of the total area of the planet. Edges of the Antarctic plate reach the 28th parallel of the southern latitude, crossing the differential zone of the $40^{\text {th }}$ latitudes with opposite directed transgressions and regressions of the ocean, which are also the result of a latitudinal change in the direction of the Coriolis forces. Taking into account the polar location of the Antarctic plate relative to other tectonic plates, it should be noted that the Coriolis forces should mainly lead to the rotation of the plate, but plates that cover the equatorial zone, due to these forces should receive 
a linear displacement in the west direction. Angular velocity of the Antarctic plate should be related to the angular velocity of the Earth's rotation, and with the changes of angular velocities it should take or give the angular momentum. The law of conservation of angular momentum must also act in the system: core, mantle, Earth's crust, atmosphere and ocean.

For today, we have accumulated long-term observations on permanent GNSS-stations located on all continents, and on the basis of these data it is possible to reliably monitor changes of the rotational parameters of tectonic plates in time and analyze their correlation with the kinematic parameters of the atmosphere and the ocean, which are determined from geophysical observations.

In order to establish possible regularities between the changes in the angular momentum of the Antarctic tectonic plate and the Earth, the atmosphere, and the ocean, we implemented study of these parameters on the basis of long-term geophysical and GNSSmeasurements.

Performed work on the study of the unevenness of the rotary motion of the Antarctic tectonic plate and the relationship between the changes in its angular momentum and changes in the angular momentum of the Earth's, atmospheric and oceanic masses are the continuation of previous studies implemented in 2015, made by order of the NASC (National Antarctic Scientific Center). The initial data are supplemented by time series of GNSS-stations, and the method of determining the rotational parameters is significantly improved. [Tretyak et al., 2017].

\section{Methodology and results}

\section{Input data for calculation of rotational parameters of Antarctic tectonic plate}

At the first stage, we select time series of daily solutions of all existing permanent GNSS-stations located in Antarctica. There were 71 stations in 2014. Daily solutions for each station were calculated by Nevada Geodetic Laboratory [NGL, 2016] using software GIPSY-OASIS-II with Precise Point Positioning, and the daily coordinates of the stations are available on the NGL website in the IGS08 reference system [Tretyak et al., 2017].

At the second stage we selected stations that did not have significant gaps in time series (Fig. 2). For example, the HAAZ station was removed from the database because it had a gap in the time series of about two years (Fig. 2,c). Additionally, stations with length of time series of less than 5 years were removed, for example CAPF station (Fig. 2, $b$ ).

28 permanent GNSS-stations were selected after filtration of data. Their measurement results for the period 1996-2014 were used to study the changes of angular momentum of the Antarctic tectonic plate. (Fig. 3) [Tretyak et al., 2017].

From Fig. 3 we can see that disposition of GNSSstations is heterogeneous due to difficulties in the development of Antarctica. In addition, the collected observations are not homogeneous in time. Table 1 shows the availability of daily solutions for each station over the years of observations [Tretyak et al., 2017].

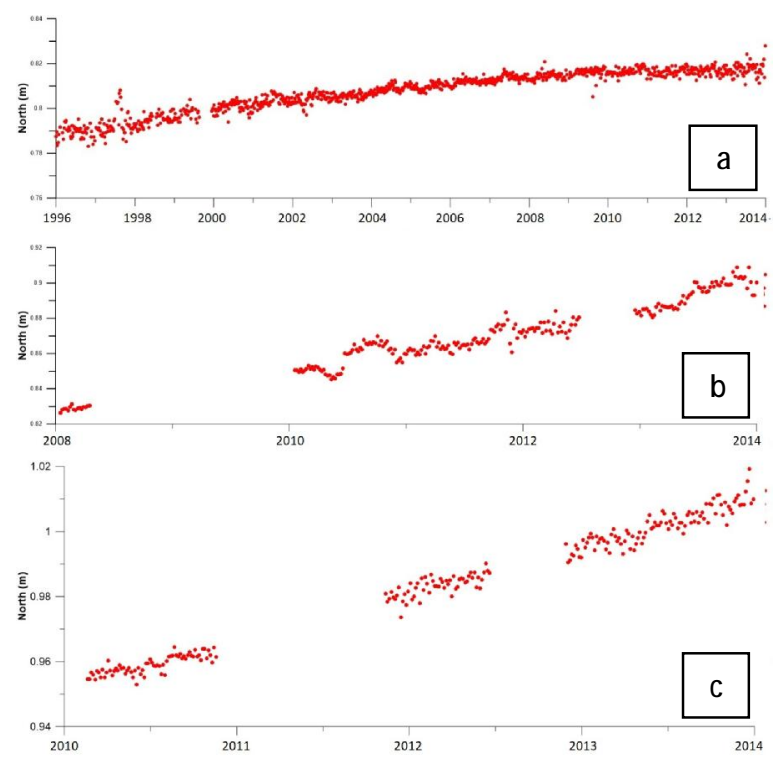

Fig. 2. Time series of daily solutions of the permanent GNSS-station CAS1 CAPF HAAZ

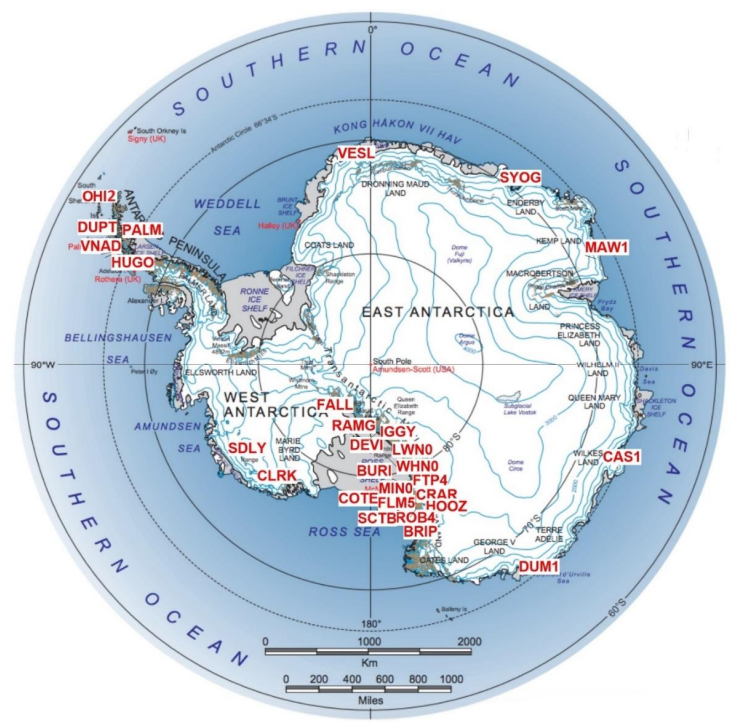

Fig. 3. The location of permanent GNSS-stations selected for researches [Tretyak et al., 2017] 


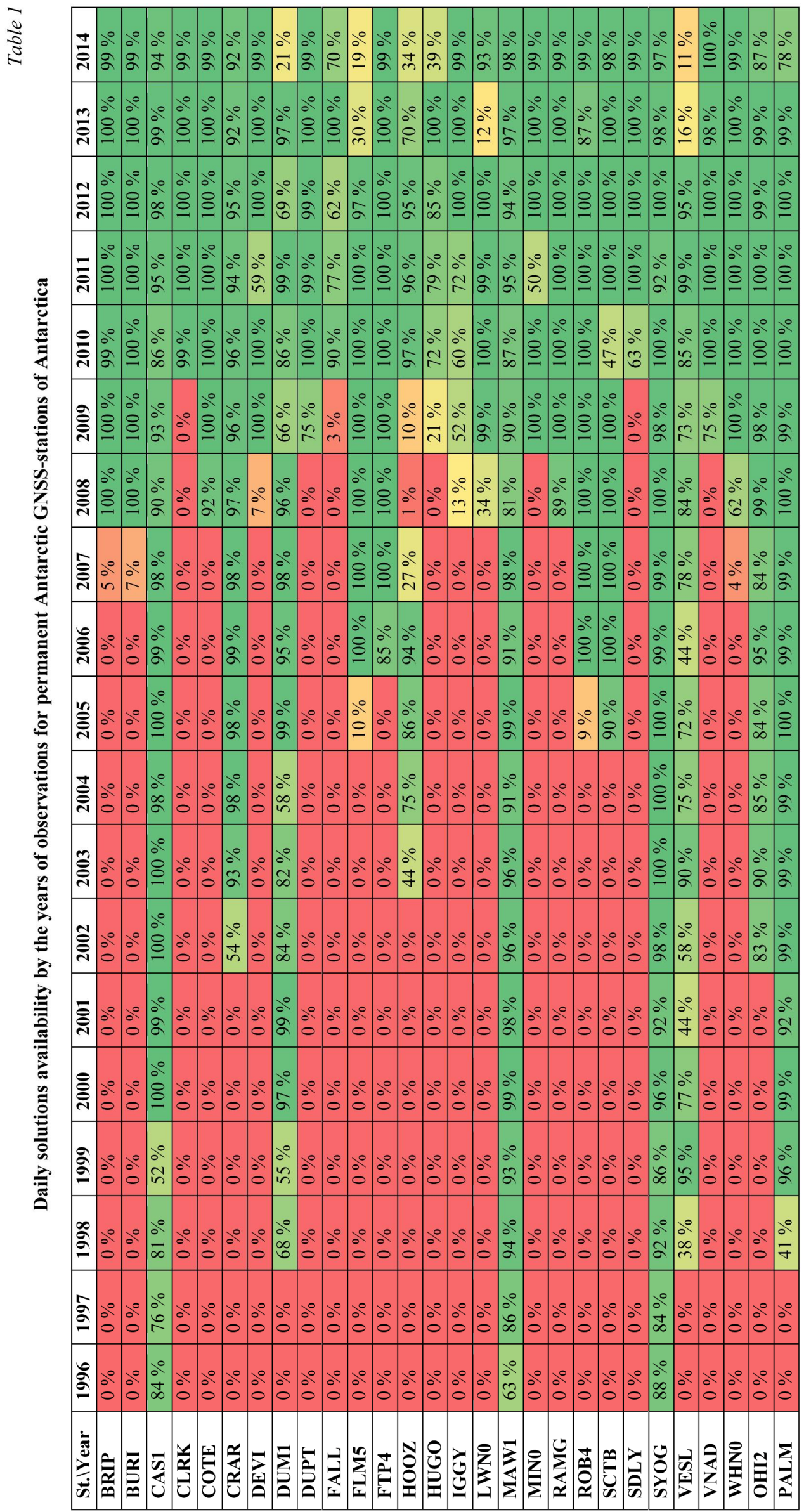


Analysis of Table 1 allows us to single out five GNSS-stations: CAS1, DUM1, MAW1, PALM, SYOG, VESL, which have the longest series of observations for a period of about 20 years. Starting from 2010, the time series of practically all stations are almost homogeneous and continuous [Tretyak et al., 2017].

\section{Determination of velocities and weights of vectors of permanent GNSS-stations}

To determine the components of the vectors of horizontal displacement velocities $V_{B}$ and $V_{L}$, we used time series, that is, daily solutions of the permanent GNSS-station.

For each solution we formulated linear equations:

$$
\begin{gathered}
x_{i}=V_{B} \cdot t_{i}+c_{B} ; \\
y_{i}=V_{L} \cdot t_{i}+c_{L},
\end{gathered}
$$

where $t_{i}$ - epoch of observation, $c_{B}, c_{L}$ - constants.

By the least squares method, we solved separately the systems of equations (1) and (2) and determined the components of the vectors of velocities of horizontal displacements $V_{B}$ and $V_{L}$, and performed estimation of the accuracy of determined parameters $m_{V_{B}}$ and $m_{V_{L}}$.

The weight of each equation (1), (2) depends on the continuity and uniformity of the data distribution over the observation time. Fig. 2, a presents a continuous time series of daily solutions. The weight of the continuity and uniformity of the data distribution of such time series is equal to 1. Fig. 4 shows time series with gaps and their irregular distribution in observation interval. Correspondently weights of these time series will be different from 1 . For the weights computation it is necessary to determine the length of the observation interval:

$$
\Delta t=t_{2}-t_{1}
$$

where $t_{1}, t_{2}$ - the starting and final epoch of observation, respectively.

Average length of whole observation interval of data is determined, independently with a number of solutions:

$$
s_{r}=\frac{t_{1}+t_{2}}{2}
$$

Average epoch of all existing solutions is computed as:

$$
s_{t}=\frac{\sum_{i=1}^{n} t_{i}}{n},
$$

where $t_{i}$ - epoch of $i$-th solution, $n$ - number of solutions which could be different from the average length of observations interval $S_{r}$ (Fig. 4).

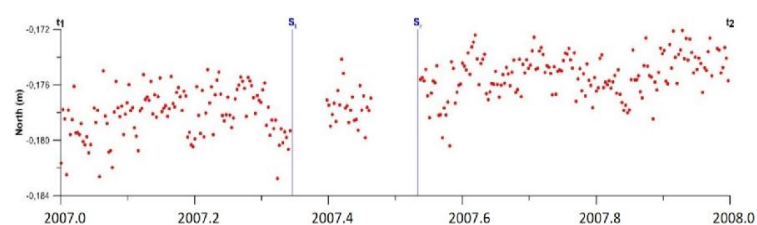

Fig. 4. Time series with gaps and their irregular distribution of permanent GNSS-station SYOG [Tretyak et al., 2017]

A weight due to data irregularity is computed as

$$
P_{1}=1-\frac{2\left|s_{r}-s_{t}\right|}{\Delta t} .
$$

The bigger the deviation, that is the difference $s_{r}-s_{t}$, the smaller is the weight, but if $s_{r}=s_{t}$, then the weight will be equal to 1 . Determination of weight due to data continuity can be done using the following expression:

$$
P_{2}=1-\frac{4\left|\frac{\Delta t}{4}-\delta t\right|}{\Delta t},
$$

where $\delta t=\frac{\sum\left|t_{i}-s_{t}\right|}{n}-$ the sum of average residual of epochs of all available solutions from $s_{t}$.

In addition to the weights $P_{1}$ and $P_{2}$ it is necessary to enter weight $P_{3}$ to account the unevenness of the geometric distribution of stations location. In order to calculate the weight $P_{3}$ for the geometric location of the stations, it was necessary to divide the Antarctic Continent into sectors with a given step. Fig. 5 shows how the division into 20 degree sectors was carried out. Weight of each station

$$
P_{3}=\frac{1}{N},
$$

where $\mathrm{N}$ - number of stations in the sector.

Final weight of each vector components $V_{B}$ and $V_{L}$ is computed using the following expression:

$$
P=\frac{P_{1} P_{2} P_{3}}{m^{2}},
$$

where $P_{1}$ - weight for data irregularity, $P_{2}$ - weight for data of continuity, $P_{3}$ - weight for geometric location of the stations, $m^{2}-$ r.m.s. of $m_{V_{B}}$ and $m_{V_{L}}$ residuals respectively.

On the base of presented algorithm and time series of 28 permanent stations of the Antarctic Continent, the components of the vectors of horizontal velocities of permanent GNSS-stations of Antarctic tectonic plates, their accuracy and weight for the entire observation period were determined (Table 2) [Tretyak et al., 2017]. 


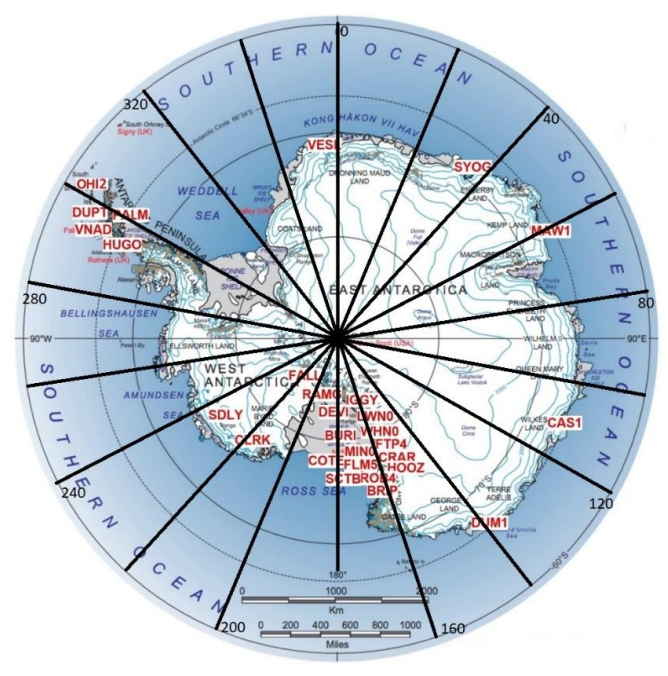

Fig. 5. Sectoral division

of the Antarctic Continent for calculation of the weight $P_{3}$

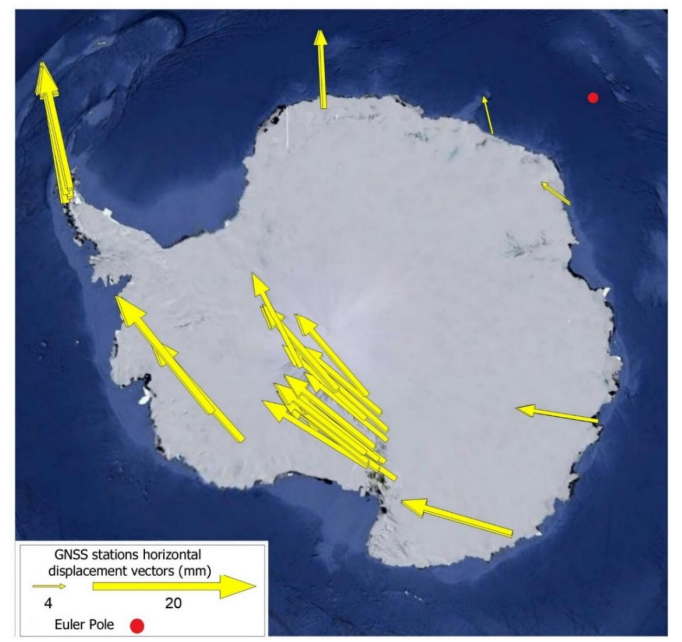

Fig. 6. Velocity vectors of the Antarctic permanent GNSS-stations for the period of 1996-2014 [Tretyak et al., 2017]

Table 2

Determined velocities of GNSS-station vectors

\begin{tabular}{|c|c|c|c|c|c|c|c|c|c|}
\hline № & $\begin{array}{l}\text { Station } \\
\text { name }\end{array}$ & B [ $\square]$ & L [ $\square]$ & $\begin{array}{c}V_{B} \\
{[\mathrm{~mm}]}\end{array}$ & $\begin{array}{c}V_{L} \\
{[\mathrm{~mm}]}\end{array}$ & $\begin{array}{c}m_{V_{B}} \\
{[\mathrm{~mm}]}\end{array}$ & $\begin{array}{c}m_{V_{L}} \\
{[\mathrm{~mm}]}\end{array}$ & $P_{B}$ & $P_{L}$ \\
\hline 1 & BRIP & -75.796 & 158.469 & -12 & 8 & 2.1 & 2.1 & 0.371 & 0.371 \\
\hline 2 & BURI & -79.147 & 155.894 & -12 & 6 & 1.9 & 2.0 & 0.372 & 0.373 \\
\hline 3 & CAS1 & -66.283 & 110.52 & -10 & 2 & 0.7 & 0.7 & 0.969 & 0.969 \\
\hline 4 & CLRK & -77.34 & 218.126 & -3 & 17 & 3.7 & 3.4 & 0.262 & 0.263 \\
\hline 5 & COTE & -77.806 & 161.998 & -12 & 8 & 2.1 & 2.0 & 0.364 & 0.365 \\
\hline 6 & CRAR & -77.848 & 166.668 & -11 & 9 & 0.8 & 1.0 & 0.656 & 0.667 \\
\hline 7 & DEVI & -81.477 & 161.977 & -12 & 7 & 2.5 & 2.7 & 0.338 & 0.318 \\
\hline 8 & DUM1 & -66.665 & 140.002 & -12 & 8 & 1.0 & 1.0 & 0.833 & 0.914 \\
\hline 9 & DUPT & -64.805 & 297.183 & 10 & 12 & 3.1 & 3.2 & 0.303 & 0.303 \\
\hline 10 & FALL & -85.306 & 216.368 & -6 & 12 & 4.1 & 4.1 & 0.268 & 0.276 \\
\hline 11 & FLM5 & -77.533 & 160.271 & -12 & 8 & 1.5 & 1.6 & 0.407 & 0.556 \\
\hline 12 & FTP4 & -78.928 & 162.565 & -12 & 8 & 1.3 & 1.4 & 0.468 & 0.467 \\
\hline 13 & HOOZ & -77.532 & 166.933 & -11 & 11 & 1.3 & 1.7 & 0.691 & 0.623 \\
\hline 14 & HUGO & -64.963 & 294.332 & 10 & 15 & 4.4 & 4.3 & 0.251 & 0.295 \\
\hline 15 & IGGY & -83.307 & 156.25 & -13 & 4 & 3.1 & 4.2 & 0.320 & 0.290 \\
\hline 16 & LWNO & -81.346 & 152.732 & -12 & 4 & 2.4 & 2.4 & 0.325 & 0.368 \\
\hline 17 & MAW1 & -67.605 & 62.871 & -2 & -4 & 0.6 & 0.6 & 0.984 & 0.983 \\
\hline 18 & MIN0 & -78.65 & 167.164 & -11 & 9 & 3.9 & 3.9 & 0.339 & 0.314 \\
\hline 19 & RAMG & -84.338 & 178.047 & -11 & 9 & 2.1 & 2.0 & 0.362 & 0.363 \\
\hline 20 & ROB4 & -77.034 & 163.19 & -12 & 9 & 1.2 & 1.4 & 0.474 & 0.484 \\
\hline 21 & SCTB & -77.849 & 166.758 & -12 & 9 & 1.3 & 1.2 & 0.543 & 0.525 \\
\hline 22 & SDLY & -77.135 & 234.025 & 1 & 19 & 5.5 & 3.9 & 0.252 & 0.249 \\
\hline 23 & SYOG & -69.007 & 39.584 & 3 & -4 & 0.6 & 0.6 & 0.981 & 0.980 \\
\hline 24 & VESL & -71.674 & 357.158 & 10 & 0 & 0.7 & 0.7 & 0.821 & 0.923 \\
\hline 25 & VNAD & -65.246 & 295.746 & 10 & 14 & 3.2 & 3.3 & 0.303 & 0.303 \\
\hline 26 & WHNO & -79.846 & 154.22 & -13 & 5 & 2.2 & 2.3 & 0.356 & 0.354 \\
\hline 27 & $\mathrm{OHI} 2$ & -63.321 & 302.099 & 10 & 15 & 1.6 & 1.9 & 0.671 & 0.667 \\
\hline 28 & PALM & -64.775 & 295.949 & 11 & 13 & 0.9 & 0.7 & 0.852 & 0.869 \\
\hline
\end{tabular}

Table 2 shows that accuracy of determination of vector components is equal to about $10 \%$ of vectors' length. Fig. 6 shows the motion of vectors of horizontal displacement velocity of the permanent GNSS-stations for the period of 1996-2014. The location of vectors has a rotational character that move in the clockwise direction [Tretyak et al., 2017]. 


\section{Methods of determination of angular velocity and Euler pole coordinates for the Antarctic tectonic plate}

The relationship between the displacement velocity of the permanent GNSS-station and the parameters of the Euler pole: the coordinates and velocity of the plate rotation (Fig. 7) can be represented by the following formulas:

$$
\begin{gathered}
V_{B}=\Omega \cdot \cos (\Phi) \cdot \sin (L-\Lambda) \\
V_{L}=\Omega \cdot(\sin (\Phi) \cdot \cos (B)- \\
-\cos (\Phi) \cdot \sin (B) \cdot \cos (L-\Lambda)),
\end{gathered}
$$

where $\Omega$ - angular velocity of plate rotation; $\Phi, \Lambda$ Euler pole coordinates; B, L - coordinates of permanent GNSS-station with determined displacement velocities in latitudinal and longitudinal directions $V_{B}, V_{L}$.

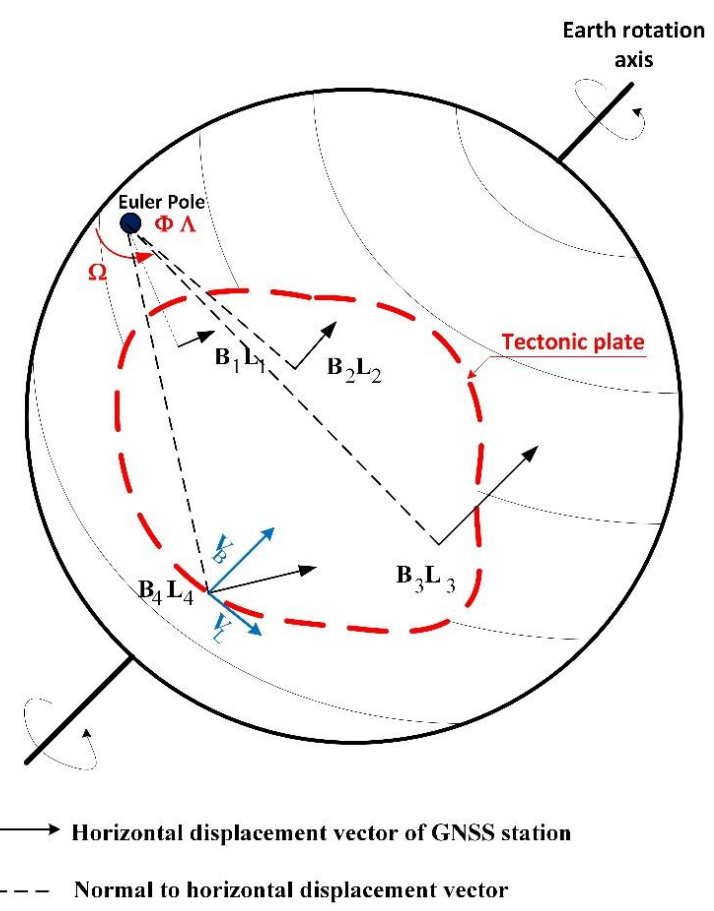

Fig. 7. Euler pole [Tretyak et al., 2017]

For each point of the set of permanent stations, non-linear equations (10-11) can be written. In these equations there are three unknowns: the Euler pole coordinates $(\Phi, \Lambda)$ and the angular velocity of plate rotation $(\Omega)$. Depending on the number of points, we will have double the number of equations, so the number of equations is always bigger than the number of unknowns (when $n \geq 2$, where $n$ is the number of points). In this regard, the determination of unknown parameters $(\Omega, \Phi, \Lambda)$ is performed by the least squares method [Tretyak and Vovk, 2016].

Using adjusted parameters of the Euler pole $(\Omega, \Phi, \Lambda)$ we determined their accuracy assessment:

$$
m_{\Omega}=\mu \cdot \sqrt{Q_{\Omega \Omega}} ;
$$

$$
\begin{gathered}
m_{\Phi}=\mu \cdot \sqrt{Q_{\Phi \Phi}} ; \\
m_{\Lambda}=\mu \cdot \sqrt{Q_{\Lambda \Lambda}},
\end{gathered}
$$

where $Q_{\Omega \Omega}, Q_{\Phi \Phi}, Q_{\Lambda \Lambda}$ - diagonal elements of the correlation matrix, $\mu=\sqrt{v^{T} \cdot \frac{v}{2 n-1}}-$ error of the unit of weight of measured vectors, $v$ - deviations of model values of displacement velocities of permanent GNSS-stations in latitudinal and longitudinal directions from measured values [Tretyak et al., 2017].

\section{Determination of rotational parameters of the} Antarctic tectonic plates for the period 1996-2014

For the entire observation period, the average angular velocity of the plate rotation and the coordinates of the average Euler pole were calculated, their accuracy estimation, and MSE of determination of model vectors of horizontal velocities are determined.

Table 3

Average values of angular velocity and coordinates of the Euler pole of the Antarctic tectonic plate

\begin{tabular}{|c|c|}
\hline$\omega[$ [“/year $]$ & 0.00074 \\
\hline$\Phi\left[{ }^{0}\right.$ Euler pole $]$ & 58.2157 \\
\hline$\Lambda\left[{ }^{\mathbf{0}}\right.$ Euler pole pa $]$ & 52.9937 \\
\hline$m_{\omega}\left[{ }^{“} /\right.$ year $]$ & 0.000008 \\
\hline$m_{\Phi}\left[{ }^{\mathbf{0}}\right]$ & 0.308 \\
\hline$m_{\Lambda}\left[{ }^{\mathbf{0}}\right]$ & 0.416 \\
\hline$m_{v_{p}}[\mathrm{~mm}]$ & 0.9 \\
\hline
\end{tabular}

The accuracy of determining the angular velocity of the plate rotation is 100 times smaller than the velocity value, and the accuracy of determination of the horizontal velocities vectors is within $1 \mathrm{~mm} /$ year [Tretyak et al., 2017].

Fig. 8 shows the position of the Euler poles, determined as averages for the period (1996-2014) in this work, as well as in other works [Drewes, 1998, 2001, 2009; Argus, 1991, 2011; SOPAC, 2016; Altamimi, 2012; Dietrich, 2001, 2004; Sella, 2002; Jiang Wei-Ping, 2009].

It should be noted that the Euler pole determined in our research is located practically with a pole defined by the SCAR for the period (1997-2004).

Based on the calculation of annual velocities of horizontal displacements of permanent stations (for the period 1996-2014), the annual parameters of the Euler pole of the Antarctic plate and its angular velocity are determined (Table 4). The annual migration of the position of the Euler pole is shown in Fig. 9 [Tretyak et al., 2017]. 


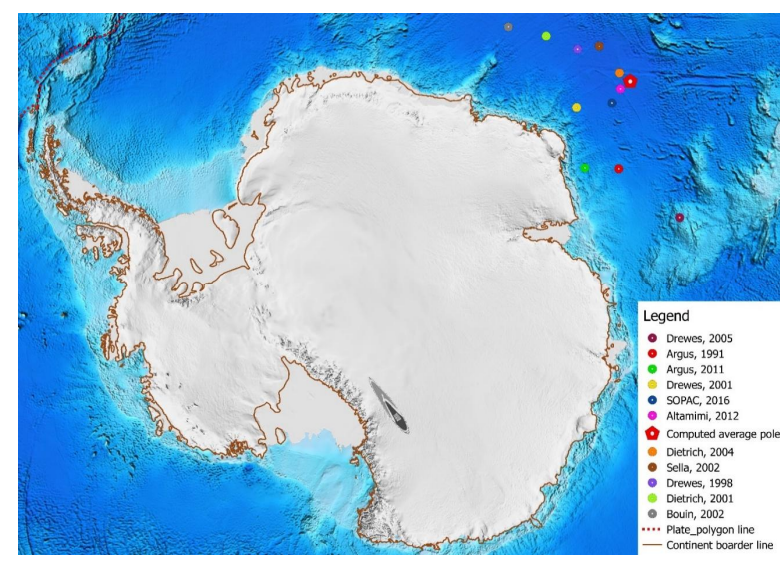

Fig. 8. Euler poles of the Antarctic tectonic plate [Tretyak et al., 2017]

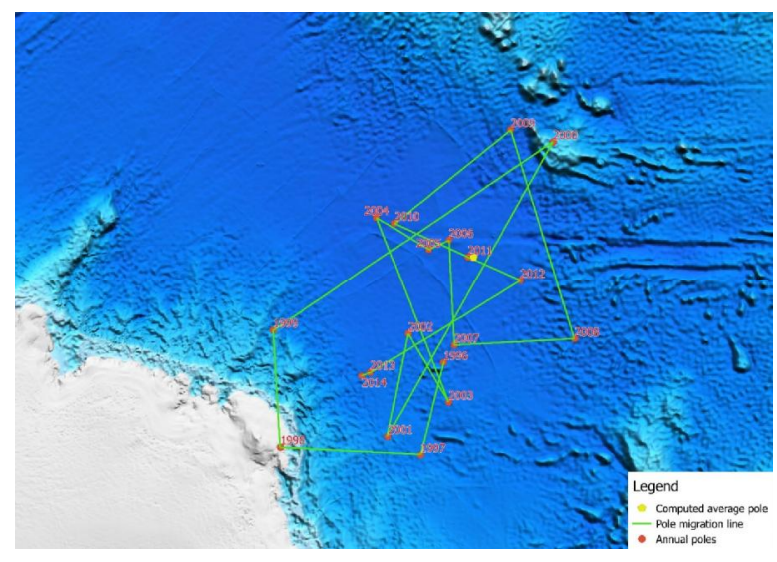

Fig. 9. The motion of Euler pole of the Antarctic tectonic plate based on the GNSS-measurements (1996-2014) [Tretyak et al., 2017]

Table 4

Determined annual parameters of the Euler pole (angular velocities and poles coordinates) and their accuracy estimation

\begin{tabular}{|c|c|c|c|c|c|}
\hline Years & 1996 & 1997 & 1998 & 1999 & 2000 \\
\hline$\omega$ [“/year] & 0.00083 & 0.00118 & 0.00103 & 0.00094 & 0.00071 \\
\hline$\Phi\left[{ }^{0}\right.$ Euler pole $]$ & 60.7776 & 62.8070 & 66.3532 & 64.3146 & 54.2651 \\
\hline$\Lambda\left[{ }^{0}\right.$ Euler pole $]$ & 57.0776 & 61.4130 & 55.7144 & 48.5908 & 50.7945 \\
\hline$m_{\omega}[“$ /year $]$ & 0.00010 & 0.00011 & 0.00020 & 0.00008 & 0.00005 \\
\hline$m_{\Phi}\left[{ }^{\mathbf{0}}\right]$ & 1.90520 & 0.91235 & 2.45059 & 1.69567 & 2.52444 \\
\hline$m_{\Lambda}\left[{ }^{\mathbf{0}}\right]$ & 3.18467 & 1.55628 & 6.95636 & 3.79690 & 3.11984 \\
\hline$m_{V_{p}}[\mathrm{~mm}]$ & 0.8 & 0.7 & 7.0 & 3.0 & 1.5 \\
\hline Years & 2001 & 2002 & 2003 & 2004 & 2005 \\
\hline$\omega$ [“/year] & 0.00084 & 0.00079 & 0.00083 & 0.00076 & 0.00075 \\
\hline$\Phi\left[{ }^{0}\right.$ Euler pole $]$ & 63.3941 & 61.1644 & 61.2747 & 59.6926 & 59.1372 \\
\hline$\Lambda\left[{ }^{0}\right.$ Euler pole $]$ & 59.2602 & 54.3568 & 59.3592 & 47.6225 & 51.0585 \\
\hline$m_{\omega}[“$ "“year] & 0.00003 & 0.00005 & 0.00003 & 0.00003 & 0.00002 \\
\hline$m_{\Phi}\left[{ }^{\mathbf{O}}\right]$ & 1.88183 & 1.74935 & 1.29964 & 1.32376 & 0.67070 \\
\hline$m_{\Lambda}\left[{ }^{\mathbf{0}}\right]$ & 4.84780 & 2.81064 & 2.05997 & 1.87300 & 0.97277 \\
\hline$m_{V_{p}}[\mathrm{~mm}]$ & 1.8 & 2.5 & 1.6 & 1.3 & 3.6 \\
\hline Years & 2006 & 2007 & 2008 & 2009 & 2010 \\
\hline$\omega[“ /$ рік] & 0.00077 & 0.00076 & 0.00078 & 0.00074 & 0.00075 \\
\hline$\Phi\left[{ }^{0}\right.$ Euler pole $]$ & 58.4879 & 60.2095 & 57.0464 & 54.9920 & 59.4045 \\
\hline$\Lambda\left[{ }^{0}\right.$ Euler pole $]$ & 51.3520 & 56.5518 & 59.8963 & 48.9331 & 48.5756 \\
\hline$m_{\omega}[“ /$ year $]$ & 0.00003 & 0.00002 & 0.00002 & 0.00002 & 0.00003 \\
\hline$m_{\Phi}\left[{ }^{\mathbf{O}}\right]$ & 1.37698 & 0.74816 & 1.06245 & 1.11181 & 1.38743 \\
\hline$m_{\Lambda}\left[{ }^{\mathbf{0}}\right]$ & 1.62137 & 1.00725 & 1.01728 & 0.86209 & 1.42594 \\
\hline$m_{V_{p}}[\mathrm{~mm}]$ & 1.5 & 5.8 & 11.5 & 6.6 & 3.1 \\
\hline Years & 2011 & 2012 & 2013 & 2014 & \\
\hline$\omega[“ /$ рік $]$ & 0.00081 & 0.00070 & 0.00089 & 0.00085 & \\
\hline$\Phi\left[{ }^{\circ}\right.$ Euler pole $]$ & 58.3523 & 57.4884 & 62.7808 & 63.0495 & \\
\hline$\Lambda\left[{ }^{0}\right.$ Euler pole $]$ & 52.7899 & 55.5839 & 54.9790 & 54.8560 & \\
\hline$m_{\omega}[“$ /year] & 0.00003 & 0.00002 & 0.00003 & 0.00004 & \\
\hline$m_{\Phi}\left[{ }^{\mathbf{O}}\right]$ & 1.42683 & 1.32607 & 1.13422 & 1.44046 & \\
\hline$m_{\Lambda}\left[{ }^{0}\right]$ & 1.38077 & 1.26414 & 1.27073 & 1.71990 & \\
\hline$m_{v_{p}}[\mathrm{~mm}]$ & 2.6 & 1.3 & 3.0 & 4.9 & \\
\hline
\end{tabular}


Fig. 10 shows charts of annual changes of latitude and longitude of the Euler pole and angular velocity of the Antarctic tectonic plate rotation.

It should be noted that there exists a relationship between the change of latitude of the Euler pole and the angular velocity of the tectonic plate rotation.
When the angular velocity decreases, the latitude of the Euler pole also decreases, and vice versa. The angular momentum of the Antarctic tectonic plate is corrected by the simultaneous change of these parameters [Tretyak et al., 2017].
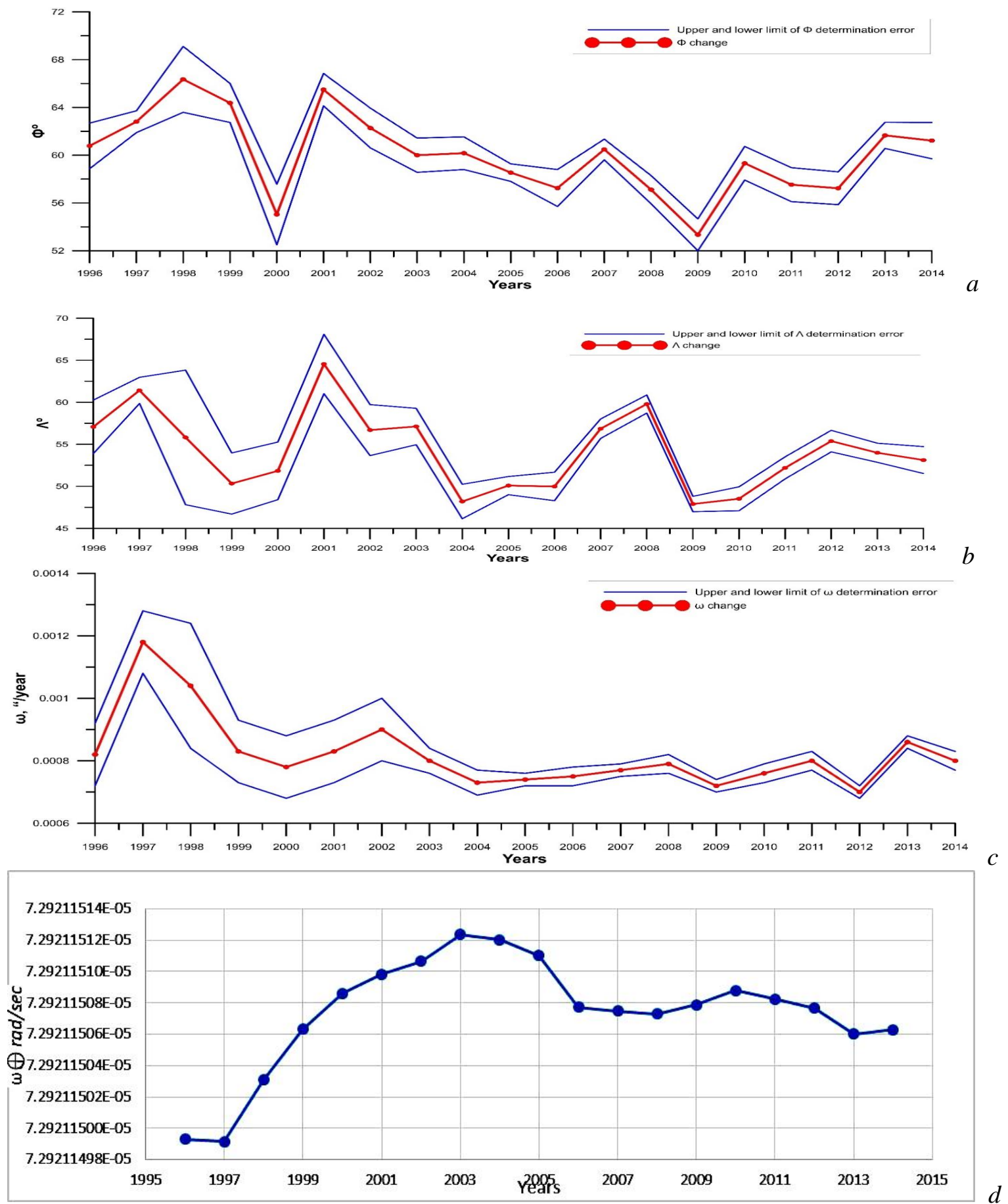

Fig. 10. Change of average annual parameters of the Euler pole of the Antarctic tectonic plate and the angular velocity of the Earth's rotation for the period 1996-2014: a - the latitude $\Phi ; \mathrm{b}$ - the longitude $\Lambda ; \mathrm{c}$ - the angular velocity of the Antarctic tectonic plate $\omega ; \mathrm{d}-$ the angular velocity of the Earth's rotation $\omega \oplus$ [Tretyak et al., 2017] 
In order to establish a possible relation between the unevenness of the rotating motions of the Earth and the Antarctic tectonic plate, the calculation of the change of average annual angular velocity of the Earth was made. To do this, we use the International Earth Rotation Service (IERS) about change of the LOD (Length of Day), expressed in ms (milliseconds), as the difference in values of periods $\left(P_{z}-P_{\Omega}\right)$, where $P_{\Omega}$ is the period of the astronomical day (86400s.), and $P_{z}$ is the period of the Earth's day (Fig. 11). Using averaged annual values of LOD the average annual angular velocity of the Earth's rotation has been calculated:

$$
\omega_{\oplus}=\Omega_{N} \cdot\left(1-\frac{L O D}{T}\right),
$$

where $\Omega_{N}=72921151.46706410^{-12} \mathrm{rad} / \mathrm{s}$ is the nominal velocity of rotation (corresponds to the rotational velocity of the average epoch 1820), T the duration of the average solar day $86400 \mathrm{~s}$. TAI.

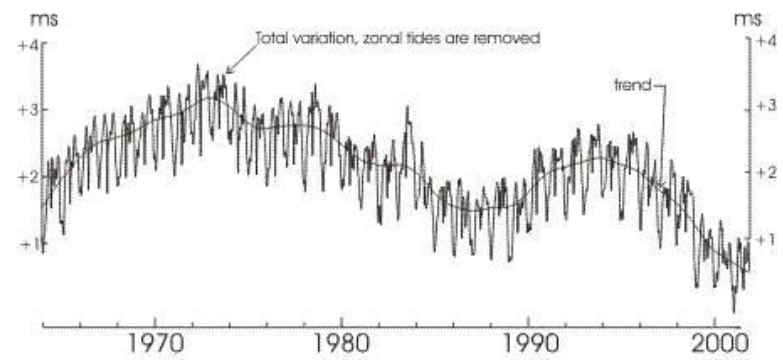

Fig. 11. Change of the parameter LOD according to IERS data

The results of calculating the change of the average annual velocity of the Earth's rotation $\omega_{\oplus}$ are shown in Fig. 10d. Comparing the change of angular velocities of rotation of the Earth $\omega_{\oplus}$ and the Antarctic tectonic plate $\omega$, one can notice that when $\omega_{\oplus}$ is increasing the angular velocity $\omega$ is decreasing and vice versa. The correlation coefficient between $\omega_{\oplus}$ for the period (1996-2014) is 0.536 , for the period (1997-2014) is 0.610 . This regularity can also be explained by the law of conservation of angular momentum. The moment of the amount of motion in a closed system (the lithosphere, the mantle, and the Earth's core) is conserved during the evolution of this system over time. Decreasing of the angular momentum of the nucleus-mantle system is compensated by increasing of the angular momentum of the lithosphere (tectonic plates). At the same time, the correlation between the angular velocity of the Earth and the Antarctic cannot be high, since the change in angular momentum depends not only on the change of angular velocities, but also on the change of position of the Earth's pole and the position of the Euler pole of the tectonic plate.

Similar dependencies are manifested in the Earth's atmospheric system-the.

\section{Determination of the moment of inertia and angular momentum of the Antarctic tectonic plate}

The established probable relationship between the rotating motion of the Earth and the Antarctic tectonic plate should be confirmed from the standpoint of the physics of rotational motion, namely, the law of conservation of angular momentum in the Earth system (nucleus, mantle, Earth crust).

In the general case, the value of the moment of inertia of an object depends on its shape and distribution of mass in volume: the more mass is concentrated further from the center of mass of body, the greater is its moment of inertia. Also its value depends on the selected axis of rotation

A solid body can be considered as a system of infinite number of material points, each with mass $m_{l}$. If the distance from each point to the axis of rotation is equal to $\eta$, then the moment of inertia of a body to the selected axis is determined:

$$
I=\sum_{i=1}^{n} m_{i} r_{i}^{2}
$$

Values $I_{x x}, I_{y y}, I_{z z}$ are the moments of inertia relative to the axes $x, y, z$ and are given as:

$$
\begin{aligned}
& I_{x x}=\int\left(y^{2}+z^{2}\right) d m \\
& I_{y y}=\int\left(x^{2}+z^{2}\right) d m . \\
& I_{z z}=\int\left(x^{2}+y^{2}\right) d m
\end{aligned}
$$

Values $I_{x y}, I_{x z}, I_{y x}, I_{y z}, I_{z x}, I_{z y}$ are

$$
\begin{aligned}
& I_{x y}=I_{y x}=-\int x y d m \\
& I_{x z}=I_{z x}=-\int x z d m . \\
& I_{y z}=I_{z y}=-\int y z d m
\end{aligned}
$$

The set of nine variables:

$$
I=\left(\begin{array}{ccc}
I_{x x} & -I_{x y} & -I_{x z} \\
-I_{y x} & I_{y y} & -I_{y z} \\
-I_{z x} & -I_{z y} & I_{z z}
\end{array}\right)
$$

is called the tensor of inertia of a body relative to a certain point, and the variables themselves are the components of this tensor.

If all six components of the inertia tensor for any coordinate system are known then we can determine the moment of inertia of a body relative to an arbitrary axis passing through the origin of the coordinates. The moment of inertia relative to the axis that does not pass through the origin of coordinates can be determined by the Huygens-Steiner theorem.

When the solid body is rotated around the stationary axis $\mathrm{z}$, the angular momentum of a solid body is calculated by the expression

$$
J=I \cdot \omega
$$

The angular momentum of a closed system of bodies remains constant, that is, it does not change over time. 
So, we developed an algorithm by which we were able to determine the angular momentum and moment of inertia of the Antarctic tectonic plate. The entire tectonic plate was divided into cells of $300 \times 300 \times$ $\times 300$ meters. For each such cell, the spatial coordinates $\mathrm{x}, \mathrm{y}, \mathrm{z}$, as well as the densities according to the CRUST 2.0 model were determined (Fig. 12).

Model CRUST 2.0 is one of the most reliable models of the Earth's crust. Spatial distribution of layer thicknesses of CRUST 2.0 is determined according to seismic tomography. However, the disagreements with other models of the Antarctic crust are very significant [Baranov et al., 2013] and can reach up to $24 \mathrm{~km}$ in the thickness of Earth's crust.

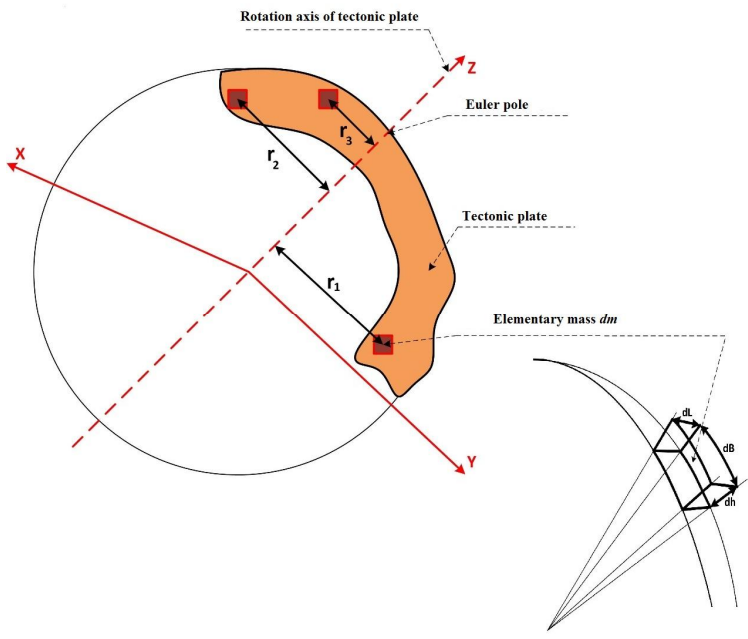

Fig. 12. Calculation of the inertia moment of the Antarctic tectonic plate

The territory of Antarctica is characterized by sharp changes in the thicknesses and physical properties of the layers. The heterogeneous spatial distribution of layers of the Earth's crust of Antarctica is caused by the complexity of its tectonic structure formed by the platforms, orogenes, structure of depression, and the intersection of extensive midoceanic ridges with the Trans-Antarctic Mountain Range. The continental crust of Antarctica can be divided into three groups: 1) the oldest Archean and Proterozoic crust of East Antarctica with a thickness of $36-56 \mathrm{~km}$ (on average $41 \mathrm{~km}$ ), 2) the continental crust of Transantarctic mountains, the Antarctic Peninsula and basin of Wilkes with thickness of $30-40 \mathrm{~km}$ (on average $30 \mathrm{~km}$ ); 3) the youngest continental crust of the Western Antarctic rift system with a thickness of 16-28 km (on average $26 \mathrm{~km}$ ). The average depth of the whole continental crust is $33.8 \mathrm{~km}$ [Baranov et al., 2013].

The CRUST 2.0 model is divided into cells of $2 \times 2$ degrees and consists of 360 key Id-profiles. Each individual profile is a 7-layer ID-model with values: 1) ice, 2) water, 3) soft sediment layer, 4) solid sediment layer, 5) upper Earth crust, 6) middle Earth crust, 7) lower Earth crust. Layers 5, 6, 7 correspond to the consolidated Earth crust, which differ in the velocity of seismic waves-R and are characterized by different petrological composition. Layer 5 consists of granites (density: $2,6-2,8 \mathrm{~g} / \mathrm{cm}^{3}$, the speed of seismic waves P: $5,7-6,3 \mathrm{~km} / \mathrm{s}$ ); layer 6 is an intermediate between granites and basalts (density: $2.8-2.9 \mathrm{~g} / \mathrm{cm}^{3}$, velocity of seismic waves P: $6.4-6.7 \mathrm{~km} / \mathrm{s}$ ); layer 7 consists of basalts (density: $2.9-3.1 \mathrm{~g} / \mathrm{cm}^{3}$, velocity of seismic waves P: $6.8-7.4 \mathrm{~km} / \mathrm{s}$ ). In addition, for each of the layers, the values of the longitudinal $\mathrm{Vp}$ (primary wave), transverse Vs (second wave) seismic waves and density $\rho$ of the Earth are given on the grid $2 \times 2: 1)$ ice $\rho=0.92 \mathrm{~g} / \mathrm{cm}^{3} ; 2$ ) water $\rho=1.02 \mathrm{~g} / \mathrm{cm}^{3}$; 3) soft sediment layer $\rho=1.7 \mathrm{~g} / \mathrm{cm}^{3}$; 4) solid sediment layer $\rho=2.3 \mathrm{~g} / \mathrm{cm}^{3}$; 5) upper crust $\rho=2.6 \mathrm{~g} / \mathrm{cm}^{3}$; 6) average crust $\rho=2.9 \mathrm{~g} / \mathrm{cm}^{3}$; 7) lower crust: $\rho=$ $=3.05 \mathrm{~g} / \mathrm{cm}^{3}$. Topography and bathymetry are selected according to the global model ETOPO5 [https://www.ngdc.noaa.gov/mgg/global/etopo5.HTML].

Fig. 13 shows the distribution of the crustal thickness of the Antarctic tectonic plate. The maximum thickness of ice is $4 \mathrm{~km}$. Soft and hard sedimentary deposits are concentrated mainly on the edge of the Antarctic continent and their depth is up to $3 \mathrm{~km}$. The thickness of the upper crust is $17 \mathrm{~km}$ and the thickness of the middle and lower crust is $15 \mathrm{~km}$.

Fig. 14 shows the distribution of the crust of the Antarctic tectonic plate according thickness. The thickness of the crust is within the range from 20 to $45 \mathrm{~km}$.

( $\boldsymbol{a}-\boldsymbol{a}$ transversal section, $\boldsymbol{b}-\boldsymbol{b}$ longitudinal section, $\boldsymbol{c}$-c section passing through the Euler pole and the south pole of the Earth).

According to the CRUST 2.0 model, the profiles of the crust thicknesses were created: transversal profile $\boldsymbol{a}-\boldsymbol{a}$ (Fig. 15), longitudinal profile $\boldsymbol{b}-\boldsymbol{b}$ (Fig. 16), profile passing through the Euler pole and the south pole of the Earth $\boldsymbol{c}-\boldsymbol{c}$ (Fig. 17).

Since the tectonic plate rotates around the Euler pole, it should be noted that the profile $\boldsymbol{a}-\boldsymbol{a}$, which represents the sliding surface on the upper mantle, is much smoother than the $\boldsymbol{b}-\boldsymbol{b}$ and $\boldsymbol{c}-\boldsymbol{c}$ profiles.

The smoothing of this surface on profile a-a, can be presumed by the many-millions in the time rotation of a tectonic plate.

Dissection of surface MOHO (bottom crust) on profiles $\boldsymbol{b}-\boldsymbol{b}$ and $\boldsymbol{c}-\boldsymbol{c}$ is the result of isostatic impact of glacial dome.

Using average annual parameters of the Euler pole and models CRUST 2.0, the annual tensors of inertia moment are determined. For example the tensor of inertia of the Antarctic plate relatively to the Euler pole for 1996 is given in Table 5.

Table 5

Inertia tensor parameters of the Antarctic plate relatively to the Euler pole for 1996

\begin{tabular}{|c|ccc|}
\hline Name & \multicolumn{3}{|c|}{ Inertia tensor } \\
\hline Moment \\
of inertia \\
$\begin{array}{c}\text { of the } \\
\text { Euler pole }\end{array}$ & $\left(\begin{array}{ccc}2.18 \cdot 10^{34} & -5.19 \cdot 10^{33} & -4.98 \cdot 10^{33} \\
-5.19 \cdot 10^{33} & 1.42 \cdot 10^{34} & -9.10 \cdot 10^{33} \\
-4.98 \cdot 10^{33} & -9.10 \cdot 10^{33} & 2.44 \cdot 10^{34}\end{array}\right)$ \\
\hline
\end{tabular}




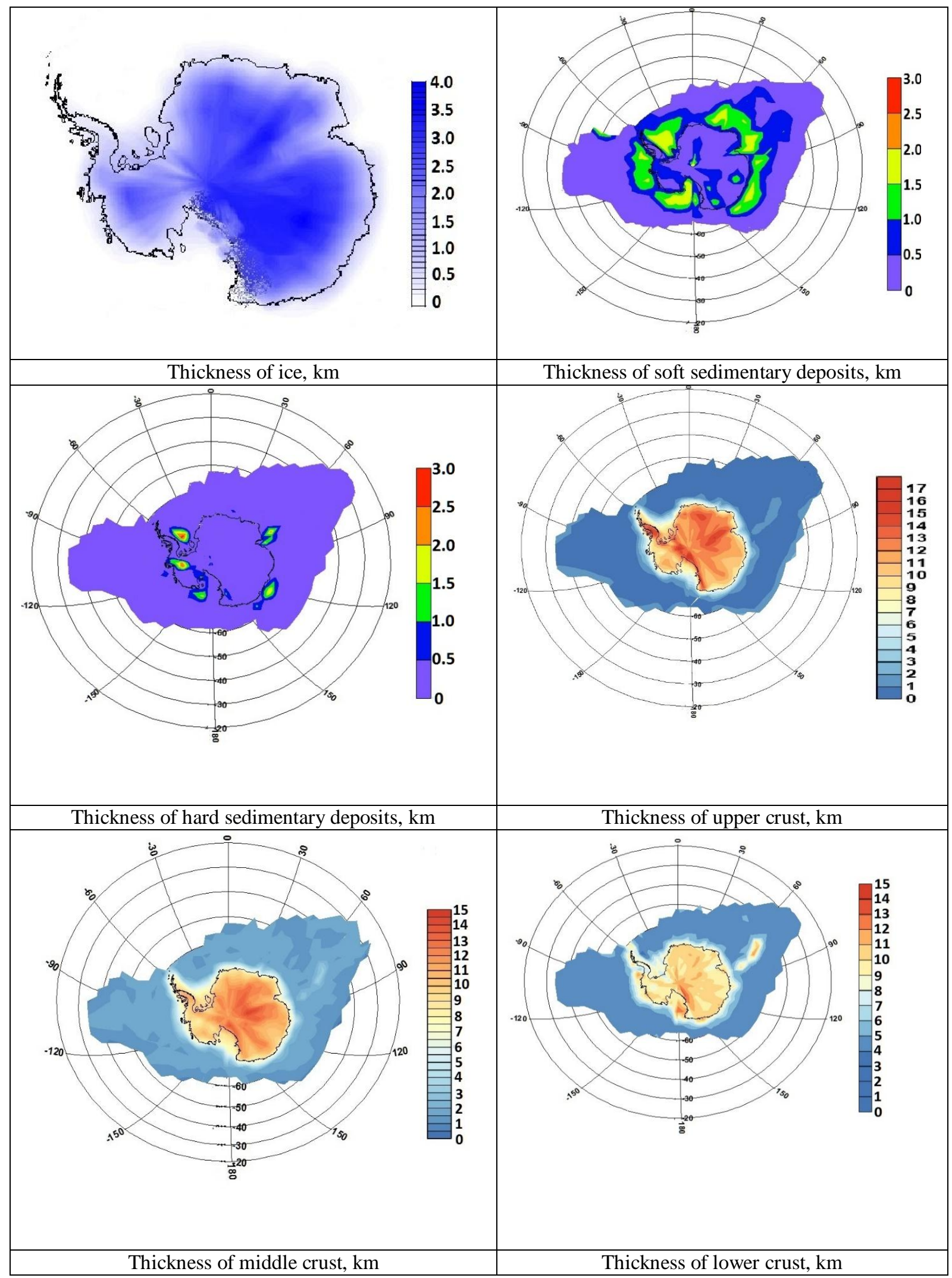

Fig. 13. Distribution of the crustal thicknesses of the Antarctic tectonic plate 
Fig. 14. Total thickness of the crust of the Antarctic tectonic plate
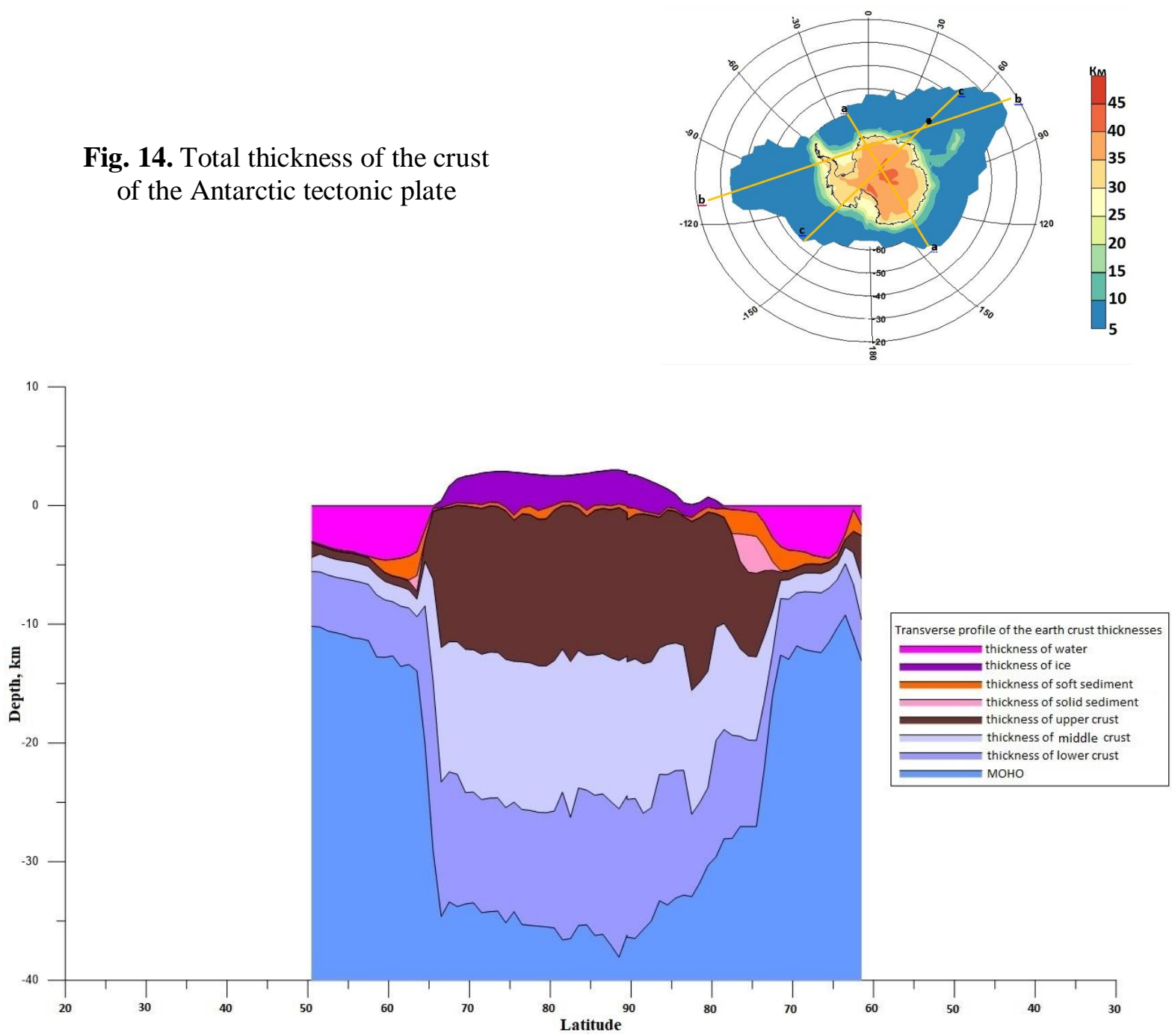

Fig. 15. Transverse profile $\boldsymbol{a}$ - $\boldsymbol{a}$ of the distribution of thickness of geological layers of the Antarctic tectonic plate

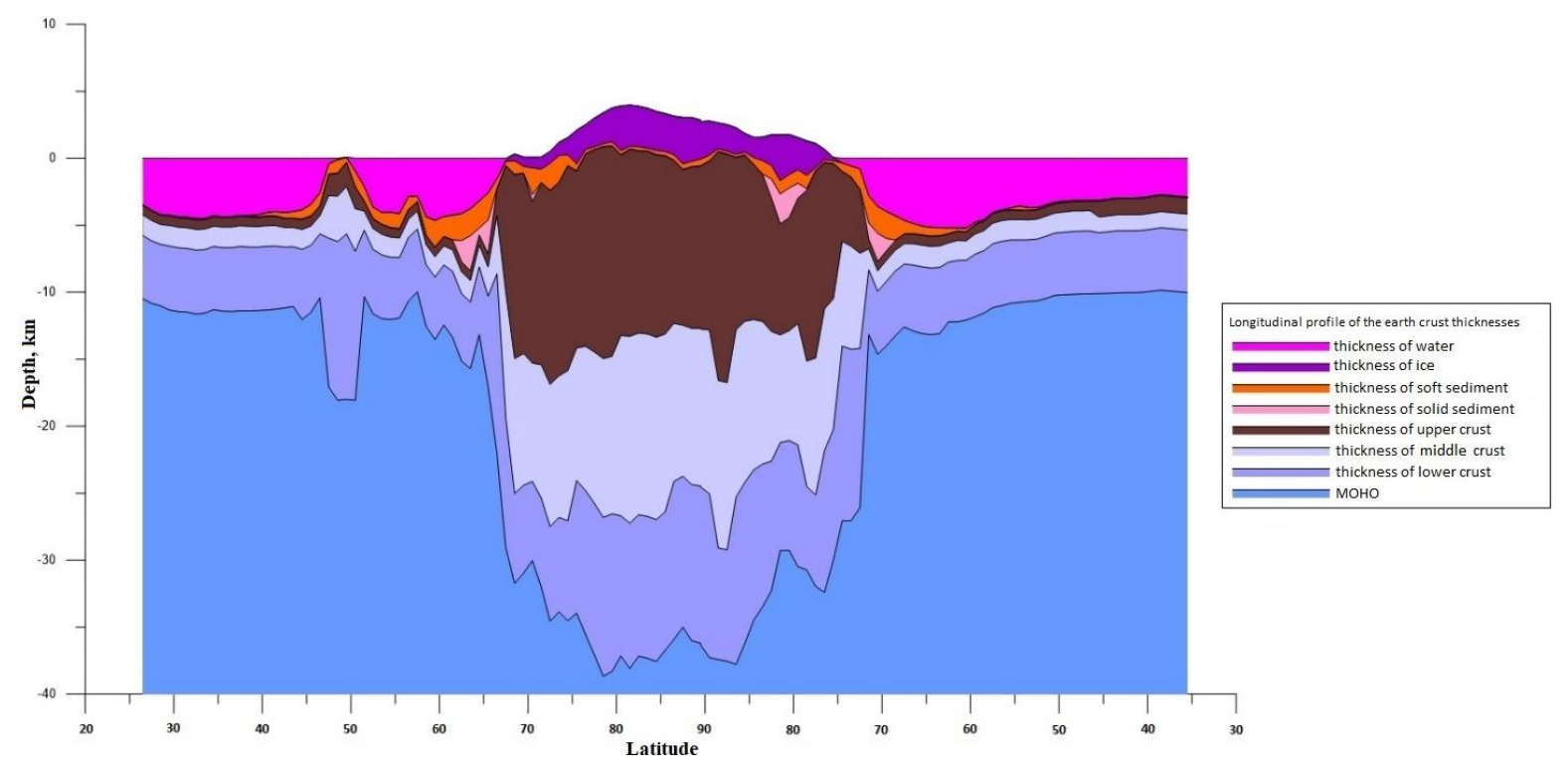

Fig. 16. Longitudinal profile $\boldsymbol{b}-\boldsymbol{b}$ of the distribution of thickness of geological layers of the Antarctic tectonic plate 


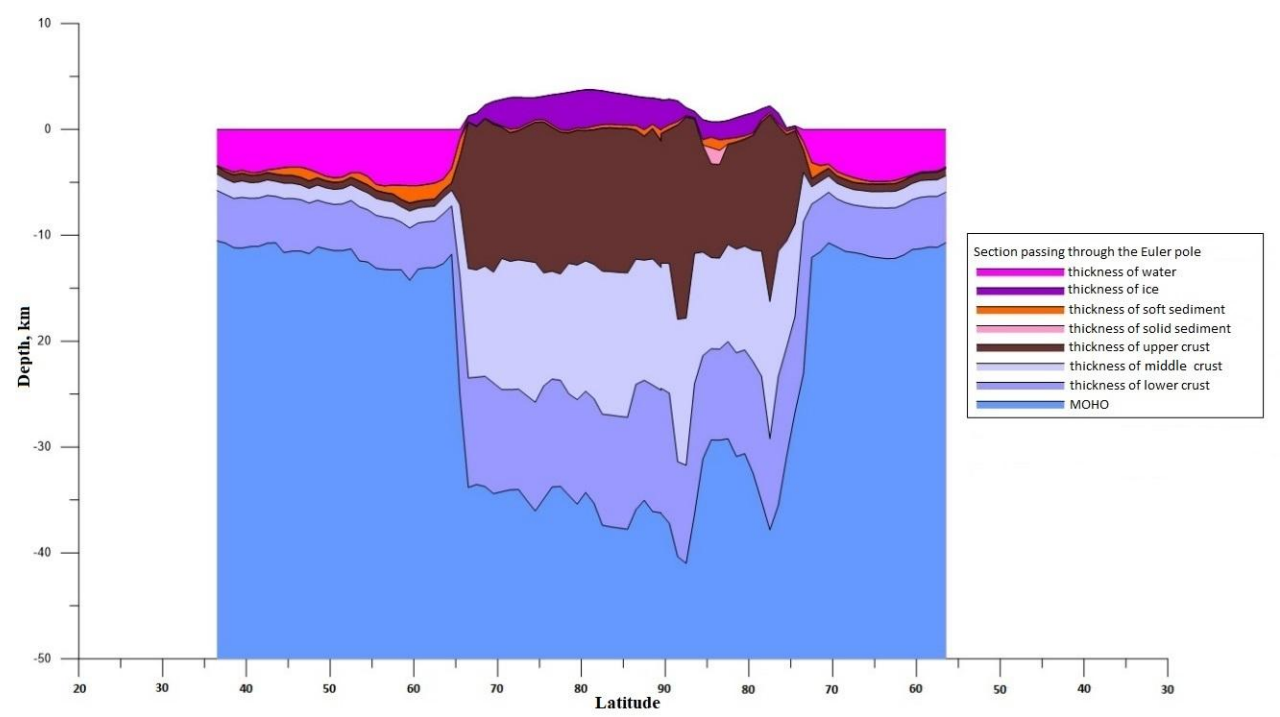

Fig. 17. Profile $\boldsymbol{c}-\boldsymbol{c}$ of the distribution of thickness of geological layers o

$\mathrm{f}$ the Antarctic tectonic plate passing through the Euler pole and the south pole of the Earth

Table 6

Inertia tensor parameters of the Antarctic plate relatively to the South Pole of the Earth for 1996

\begin{tabular}{|c|ccc|}
\hline Name & \multicolumn{3}{|c|}{ Inertia tensor } \\
\hline Moment of \\
$\begin{array}{c}\text { inertia of the } \\
\text { South Pole of } \\
\text { the Earth }\end{array}$ & $\left(\begin{array}{ccc}1.23 \cdot 10^{34} & -1.82 \cdot 10^{33} & -5.88 \cdot 10^{16} \\
-1.82 \cdot 10^{33} & 5.57 \cdot 10^{33} & -1.19 \cdot 10^{17} \\
-5.88 \cdot 10^{16} & -1.19 \cdot 10^{17} & 1.79 \cdot 10^{34}\end{array}\right)$ \\
\hline
\end{tabular}

In addition, using the data of 1996, the moments of inertia of the Antarctic plate in relation to the South
Pole of the Earth, or so-called spin moments of inertia, have been determined. The results are given in Table 6.

The inertia moment of the Antarctic plate determined relative to the south pole is less than the inertia moment of the Antarctic tectonic plate determined relatively to the Euler pole. This indicates that the south pole is much closer to the center of mass of the Antarctic plate than the Euler pole, and that the rotating motion of the Antarctic tectonic plate is influenced by the tensions of neighbouring tectonic plates.

Table 7

Total average annual moment of inertia and angular momentum of the Antarctic tectonic plate and their annual changes

\begin{tabular}{|l|c|c|c|c|}
\hline Years & $\begin{array}{c}\text { Inertia moment } \\
\left(\mathrm{kg} \cdot \mathrm{m}^{2}\right)\end{array}$ & $\begin{array}{c}\text { Angular momentum } \\
\left(\mathrm{kg} \cdot \mathrm{m}^{2} \cdot \mathrm{rad} / \mathrm{s}\right)\end{array}$ & $\begin{array}{c}\text { Change of inertia } \\
\text { moment }\left(\mathrm{kg} \cdot \mathrm{m}^{2}\right)\end{array}$ & $\begin{array}{c}\text { Change of angular } \\
\text { momentum }\left(\mathrm{kg} \cdot \mathrm{m}^{2} \cdot \mathrm{rad} / \mathrm{s}\right)\end{array}$ \\
\hline 1996 & $3.018 \cdot 10^{34}$ & $3.827 \cdot 10^{18}$ & 0 & 0 \\
\hline 1997 & $2.811 \cdot 10^{34}$ & $5.109 \cdot 10^{18}$ & $-2.070 \cdot 10^{33}$ & $1.282 \cdot 10^{18}$ \\
\hline 1998 & $3.062 \cdot 10^{34}$ & $3.645 \cdot 10^{18}$ & $2.510 \cdot 10^{33}$ & $-1.463 \cdot 10^{18}$ \\
\hline 1999 & $2.703 \cdot 10^{34}$ & $3.463 \cdot 10^{18}$ & $-3.590 \cdot 10^{33}$ & $-1.826 \cdot 10^{17}$ \\
\hline 2000 & $3.665 \cdot 10^{34}$ & $4.392 \cdot 10^{18}$ & $9.620 \cdot 10^{33}$ & $9.293 \cdot 10^{17}$ \\
\hline 2001 & $2.569 \cdot 10^{34}$ & $3.282 \cdot 10^{18}$ & $-1.096 \cdot 10^{34}$ & $-1.110 \cdot 10^{18}$ \\
\hline 2002 & $2.872 \cdot 10^{34}$ & $3.978 \cdot 10^{18}$ & $3.030 \cdot 10^{33}$ & $6.962 \cdot 10^{17}$ \\
\hline 2003 & $3.097 \cdot 10^{34}$ & $3.777 \cdot 10^{18}$ & $2.250 \cdot 10^{33}$ & $-2.006 \cdot 10^{17}$ \\
\hline 2004 & $3.120 \cdot 10^{34}$ & $3.599 \cdot 10^{18}$ & $2.300 \cdot 10^{32}$ & $-1.782 \cdot 10^{17}$ \\
\hline 2005 & $3.281 \cdot 10^{34}$ & $3.720 \cdot 10^{18}$ & $1.610 \cdot 10^{33}$ & $1.207 \cdot 10^{17}$ \\
\hline 2006 & $3.423 \cdot 10^{34}$ & $3.940 \cdot 10^{18}$ & $1.420 \cdot 10^{33}$ & $2.199 \cdot 10^{17}$ \\
\hline 2007 & $3.049 \cdot 10^{34}$ & $3.624 \cdot 10^{18}$ & $-3.740 \cdot 10^{33}$ & $-3.156 \cdot 10^{17}$ \\
\hline 2008 & $3.395 \cdot 10^{34}$ & $4.117 \cdot 10^{18}$ & $3.462 \cdot 10^{33}$ & $4.929 \cdot 10^{17}$ \\
\hline 2009 & $3.893 \cdot 10^{34}$ & $4.283 \cdot 10^{18}$ & $4.978 \cdot 10^{33}$ & $1.655 \cdot 10^{17}$ \\
\hline 2010 & $3.206 \cdot 10^{34}$ & $3.721 \cdot 10^{18}$ & $-6.869 \cdot 10^{33}$ & $-5.615 \cdot 10^{17}$ \\
\hline 2011 & $3.381 \cdot 10^{34}$ & $4.154 \cdot 10^{18}$ & $1.745 \cdot 10^{33}$ & $4.327 \cdot 10^{17}$ \\
\hline 2012 & $3.398 \cdot 10^{34}$ & $3.659 \cdot 10^{18}$ & $1.788 \cdot 10^{32}$ & $-4.952 \cdot 10^{17}$ \\
\hline 2013 & $2.942 \cdot 10^{34}$ & $3.873 \cdot 10^{18}$ & $-4.563 \cdot 10^{33}$ & $2.147 \cdot 10^{17}$ \\
\hline 2014 & $2.989 \cdot 10^{34}$ & $3.672 \cdot 10^{18}$ & $4.700 \cdot 10^{32}$ & $-2.014 \cdot 10^{17}$ \\
\hline
\end{tabular}


Table 7 shows the total average annual moment of inertia, angular momentum of the Antarctic tectonic plate and their changes for the period 1996-2014.

\section{The relationship of angular momentums of the Earth and Antarctic tectonic plate}

The angular momentum of the Earth is a constant value. However, the position of the rotation axis is changing in the body of the Earth and the angular velocity is changing. These two parameters should compensate each other so that the angular momentum of the Earth will be constant.

In addition, each tectonic plate has its own angular momentum and the sum of these angular momentums (nucleus, mantle, tectonic plates, ocean, and atmosphere) creates the angular momentum of the Earth. Due to the fact that the atmospheric, oceanic masses and tectonic plates are moving, their angular momentum is changing, but their sum is always a constant value.

Earth tides play a prominent role in the variability of velocity of the Earth rotation with a period of less than one month. The tidal power stretches the Earth along the straight line, which connects its center with the center of the perturbed body - the Moon or the Sun. In this case, the compression of the Earth increases when the axis of stretching coincides with the plane of the equator, and decreases when the axis of stretching deviate to the tropics. The moment of inertia of the compressed earth is greater than the non-deformed globular planet. In addition, since the angular momentum of the Earth (that is, the product of its moment of inertia on the angular velocity) must remain constant, the speed of rotation of the compressed Earth is less than when it is undistorted. Declinations of the Moon and the Sun and distances from the Earth to the Moon and the Sun are constantly changing under the motion of the Moon and the EarthMoon system. Therefore, the tidal power varies in time. Accordingly, the compression of the Earth changes which ultimately causes tidal unevenness of its rotation. The most significant variations of rotational velocity are with the half-month and month periods.

Table 8 shows the conditional annual angular momentum of the Earth and its changes for the period 1996-2014. It is calculated only based on the change of the angular velocity of the Earth's rotation.

Fig. 18 shows the change of annual angular momentum of the Antarctic tectonic plate and the angular momentum of the Earth. As seen from the figure, the angular momentum of the Antarctic tectonic plate and the conditional angular momentum of the Earth are asynchronous, that is, when increasing angular momentum of the Earth, the angular momentum of the Antarctic plate decreases. Only in two cases in 2001 and 2007, did changes of the angular momentums of the Earth and the Antarctic plate coincide. This asynchrony confirms the law of conservation of angular momentum.

Table 8

Conditional annual angular momentum of the Earth and its changes for the period 1996-2014

\begin{tabular}{|c|c|c|c|}
\hline Years & $\begin{array}{r}\text { Angular momentu } \\
\left(\mathrm{kg} \cdot \mathrm{m}^{2} \cdot \mathrm{r}\right.\end{array}$ & $\begin{array}{l}\mathrm{m} \text { of the Earth } \\
\mathrm{ad} / \mathrm{s})\end{array}$ & $\begin{array}{c}\text { Change of angular momentum } \\
\text { of the Earth }\left(\mathrm{kg} \cdot \mathrm{m}^{2} \cdot \mathrm{rad} / \mathrm{s}\right)\end{array}$ \\
\hline 1996 & 7.09012340 & $77 \cdot 10^{33}$ & 0 \\
\hline 1997 & 7.09012340 & $63 \cdot 10^{33}$ & $-1.468 \cdot 10^{24}$ \\
\hline 1998 & 7.09012344 & $43 \cdot 10^{33}$ & $3.808 \cdot 10^{25}$ \\
\hline 1999 & 7.09012347 & $59 \cdot 10^{33}$ & $3.159 \cdot 10^{25}$ \\
\hline 2000 & 7.09012349 & $83 \cdot 10^{33}$ & $2.237 \cdot 10^{25}$ \\
\hline 2001 & 7.09012351 & $02 \cdot 10^{33}$ & $1.186 \cdot 10^{25}$ \\
\hline 2002 & 7.09012351 & $81 \cdot 10^{33}$ & $7.901 \cdot 10^{24}$ \\
\hline 2003 & 7.09012353 & $46 \cdot 10^{33}$ & $1.655 \cdot 10^{25}$ \\
\hline 2004 & 7.09012353 & $16 \cdot 10^{33}$ & $-3.043 \cdot 10^{24}$ \\
\hline 2005 & 7.09012352 & $17 \cdot 10^{33}$ & $-9.906 \cdot 10^{24}$ \\
\hline 2006 & 7.09012348 & $95 \cdot 10^{33}$ & $-3.218 \cdot 10^{25}$ \\
\hline 2007 & 7.09012348 & $73 \cdot 10^{33}$ & $-2.232 \cdot 10^{24}$ \\
\hline 2008 & 7.09012348 & $55 \cdot 10^{33}$ & $-1.757 \cdot 10^{24}$ \\
\hline 2009 & 7.09012349 & $12 \cdot 10^{33}$ & $5.678 \cdot 10^{24}$ \\
\hline 2010 & 7.09012349 & $99 \cdot 10^{33}$ & $8.684 \cdot 10^{24}$ \\
\hline 2011 & 7.09012349 & $47 \cdot 10^{33}$ & $-5.215 \cdot 10^{24}$ \\
\hline 2012 & 7.09012348 & $9 \cdot 10^{33}$ & $-5.698 \cdot 10^{24}$ \\
\hline 2013 & 7.09012347 & $31 \cdot 10^{33}$ & $-1.590 \cdot 10^{25}$ \\
\hline 2014 & 7.09012347 & $55 \cdot 10^{33}$ & $2.480 \cdot 10^{24}$ \\
\hline
\end{tabular}




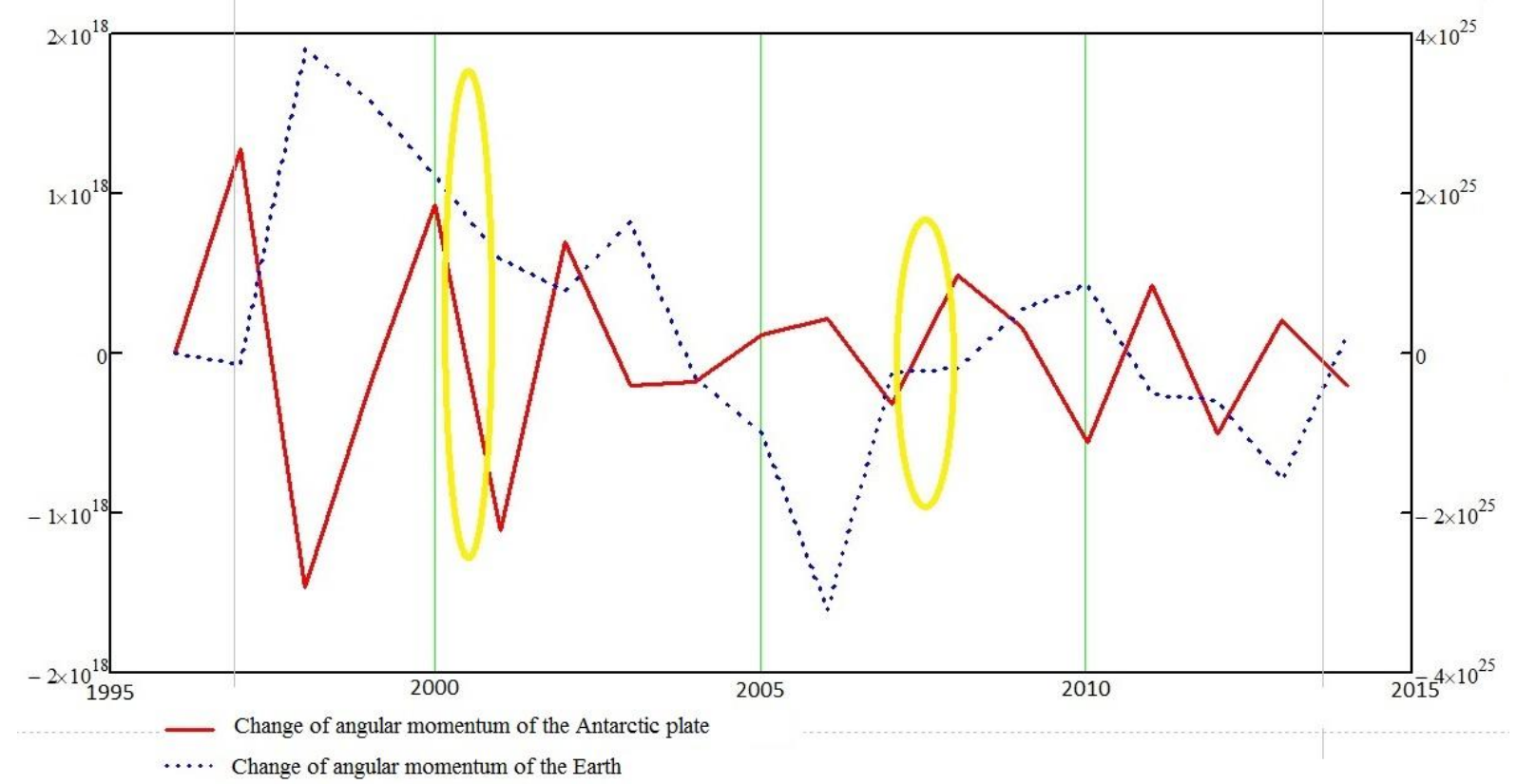

Fig. 18. Change of annual angular momentums of the Antarctic tectonic plate and the Earth

\section{Relationship of angular momentums of the Antarctic tectonic plate and the atmosphere}

The main reason for the seasonal unevenness of the Earth's rotation is the atmospheric circulation. It is known that on the average, the atmosphere moves in relation to the Earth's surface from east to west in low latitudes (eastern winds blow), and from west to east in temperate and high latitudes (western winds predominate). The angular momentum of the eastern winds is negative, and the western one is positive. One might think that these momentums compensate each other and the angular momentum of the winds of the entire atmosphere is always zero. However, calculations show that in the eastern winds this value is several times smaller than in the western winds. Therefore, the angular momentum of the winds of the entire atmosphere is not equal to zero, but on average per year is $+14 \cdot 1025 \mathrm{~kg} \cdot \mathrm{m}^{2} \cdot \mathrm{s}^{-1}$. Its value varies during the year from $+16.1 \cdot 1025 \mathrm{~kg} \cdot \mathrm{m}^{2} \cdot \mathrm{s}^{-1}$ in April and November to $+10.9 \cdot 1025 \mathrm{~kg} \cdot \mathrm{m}^{2} \cdot \mathrm{s}^{-1}$ in August.

The angular momentum is a physical quantity that cannot arise or be destroyed. It can only be redistributed. The atmosphere held by the Earth gravity rotates like a solid body together with the Earth and, in addition, rotates independently relative to the Earth's surface.. In this case, redistribution occurs between the atmosphere and the solid Earth. When the angular momentum of the atmosphere increases, (the western winds intensifies or the eastern ones weakens) the angular momentum of the Earth body decreases and its rotation slows down. When the momentum of the atmosphere decreases (the western winds weakens or the eastern ones intensifies), the Earth's rotation accelerates. The total angular momentum of the Earth and the atmosphere always remains unchanged. Changes of the absolute angular momentum of the atmosphere arise due to variations in components of the inertia tensor of the atmosphere (as a result of redistribution of air and water masses) and, due to the oscillations of components of the angular momentum of the wind.

According to the data of GGOS Atmosphere web resource [http://ggosatm.hg.tuwien.ac.at/], we can calculate the annual angular momentums of the Earth's atmosphere. The main data of the GGOS Atmosphere Web resource consists of the Atmospheric Angular Momentums (AAM) and related magnitudes from four major meteorological centers: the National Center for Environmental Prediction (NCEP), the Japan Meteorological Agency (JMA), The United Kingdom Meteorological Office (UKMO) and the European Center for Medium-Range Weather Forecasts (ECMWF).

Based on these data and the results of the calculations, the average annual angular momentums of the atmosphere for the period 1996-2014 are presented in Table 9.

Fig. 19 shows the change of angular momentum of the Antarctic tectonic plate and the atmosphere. As it can be seen from the figure, change of the angular momentums of the Antarctic tectonic plate and the atmosphere occurs synchronously, with the exception of the results of 2000 and 2004.

\section{Relationship of angular momentums of the Antarctic tectonic plates and the ocean}

The calculation of the ocean angular momentum (OAM), both its axial (AOAM) and equatorial (EOAM) components, require detailed knowledge about largescale circulation of mass under the global ocean. Thus, the researches of OAM deals with all aspects of forecasting of the ocean angular momentum and mass, including forced streams on the atmospheric and solid boundaries of the Earth, which are crucial for an integrated approach to studying the dynamics and climate of the Earth. 
Table 9

Average annual angular momentums of the atmosphere for the period 1996-2014

\begin{tabular}{|c|c|c|c|c|}
\hline \multirow[t]{2}{*}{ Years } & \multicolumn{3}{|c|}{$\begin{array}{l}\text { Tensor of inertia along the axes } \\
\qquad\left(\mathrm{kg} \cdot \mathrm{m}^{2}\right)\end{array}$} & \multirow{2}{*}{$\begin{array}{l}\text { Angular momentum } \\
\text { of the atmosphere } \\
\left(\mathrm{kg} \cdot \mathrm{m}^{2} \cdot \mathrm{rad} / \mathrm{s}\right)\end{array}$} \\
\hline & Axis $\mathrm{X}$ & Axis $\mathrm{Y}$ & Axis Z & \\
\hline 1996 & $6.574 \cdot 10^{23}$ & $-1.208 \cdot 10^{23}$ & $1.427 \cdot 10^{26}$ & 0 \\
\hline 1997 & $4.904 \cdot 10^{23}$ & $2.213 \cdot 10^{23}$ & $1.609 \cdot 10^{26}$ & $1.821 \cdot 10^{25}$ \\
\hline 1998 & $3.712 \cdot 10^{23}$ & $-1.1 \cdot 10^{23}$ & $1.511 \cdot 10^{26}$ & $-9.789 \cdot 10^{24}$ \\
\hline 1999 & $1.515 \cdot 10^{23}$ & $-1.317 \cdot 10^{23}$ & $1.412 \cdot 10^{26}$ & $-9.889 \cdot 10^{24}$ \\
\hline 2000 & $2.88 \cdot 10^{23}$ & $4.954 \cdot 10^{22}$ & $1.386 \cdot 10^{26}$ & $-2.624 \cdot 10^{24}$ \\
\hline 2001 & $2.228 \cdot 10^{22}$ & $-1.314 \cdot 10^{23}$ & $1.416 \cdot 10^{26}$ & $2.937 \cdot 10^{24}$ \\
\hline 2002 & $2.101 \cdot 10^{23}$ & $-1.18 \cdot 10^{23}$ & $1.468 \cdot 10^{26}$ & $5.243 \cdot 10^{24}$ \\
\hline 2003 & $1.267 \cdot 10^{23}$ & $-1.527 \cdot 10^{23}$ & $1.457 \cdot 10^{26}$ & $-1.103 \cdot 10^{24}$ \\
\hline 2004 & $2.947 \cdot 10^{23}$ & $-1.346 \cdot 10^{23}$ & $1.486 \cdot 10^{26}$ & $2.867 \cdot 10^{24}$ \\
\hline 2005 & $2.667 \cdot 10^{23}$ & $-2.896 \cdot 10^{23}$ & $1.442 \cdot 10^{26}$ & $-4.386 \cdot 10^{24}$ \\
\hline 2006 & $4.52 \cdot 10^{20}$ & $-2.185 \cdot 10^{23}$ & $1.458 \cdot 10^{26}$ & $1.656 \cdot 10^{24}$ \\
\hline 2007 & $-1.064 \cdot 10^{23}$ & $-3.006 \cdot 10^{23}$ & $1.37 \cdot 10^{26}$ & $-8.792 \cdot 10^{24}$ \\
\hline 2008 & $-1.941 \cdot 10^{23}$ & $-2.266 \cdot 10^{23}$ & $1.412 \cdot 10^{26}$ & $4.136 \cdot 10^{24}$ \\
\hline 2009 & $1.263 \cdot 10^{23}$ & $-5.875 \cdot 10^{22}$ & $1.448 \cdot 10^{26}$ & $3.674 \cdot 10^{24}$ \\
\hline 2010 & $2.264 \cdot 10^{23}$ & $-7.502 \cdot 10^{22}$ & $1.42 \cdot 10^{26}$ & $-2.813 \cdot 10^{24}$ \\
\hline 2011 & $-1.157 \cdot 10^{23}$ & $-2.304 \cdot 10^{23}$ & $1.415 \cdot 10^{26}$ & $-5.758 \cdot 10^{23}$ \\
\hline 2012 & $5.132 \cdot 10^{22}$ & $-1.676 \cdot 10^{23}$ & $1.372 \cdot 10^{26}$ & $-4.299 \cdot 10^{24}$ \\
\hline 2013 & $-4.458 \cdot 10^{22}$ & $-9.205 \cdot 10^{22}$ & $1.467 \cdot 10^{26}$ & $9.544 \cdot 10^{24}$ \\
\hline 2014 & $-9.286 \cdot 10^{22}$ & $3.195 \cdot 10^{20}$ & $1.446 \cdot 10^{26}$ & $-2.128 \cdot 10^{24}$ \\
\hline
\end{tabular}

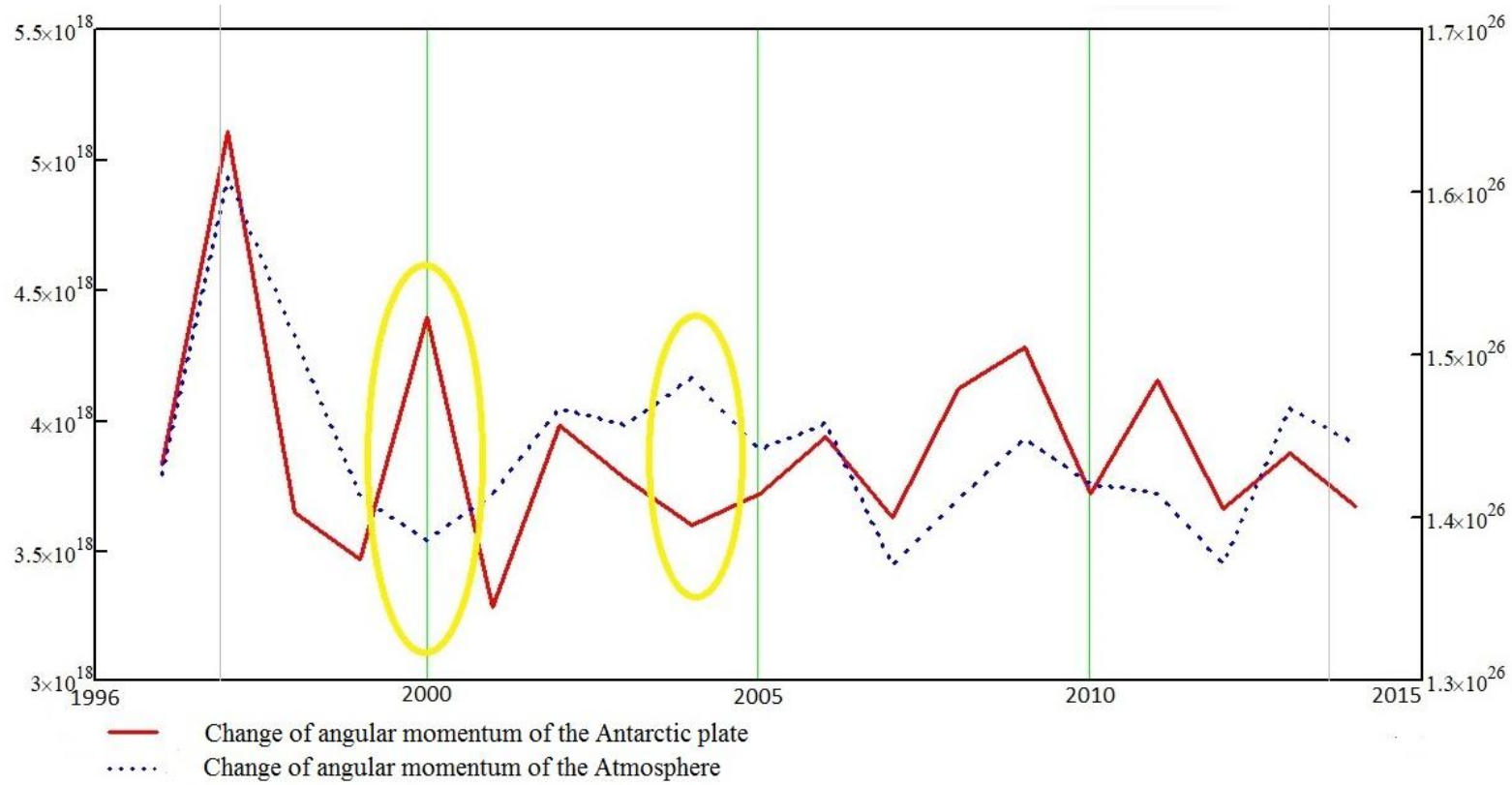

Fig. 19. Change of angular momentums of the Antarctic tectonic plate and the atmosphere 
Further discussion of various aspects of the oceanic angular momentum and changes in the Earth's rotation can be found in studies, for example, [Brosche and Sündermann, 1985; Brosche et al., 1990, 1997; Frische and Sündermann, 1990; Ponte, 1990, 1997a; Ponte and Gutzler, 1991; Eubanks, 1993; Dickey et al., 1993; Ponte and Rosen, 1994; Bryan, 1997; Segschneider and Sündermann, 1997; Dickman, 1998; Furuya and Hamano, 1998; Marcus et al., 1998; Ponte et al., 1998; Celaya et al., 1999; Johnson et al., 1999, Nastula and Ponte 1999, Ponte and Stammer 1999, 2000; Chen et al., 2000; Gross, 2000, and Wünsch, 2000].

Scientists from AER (Atmospheric and Environmental Research) had studied main parts of global weather analyzes, and conducted research and analyzed ocean models. The results were used to diagnose global prediction of angular momentum, including the exchange of angular momentums between the atmosphere, the oceans, and the solid Earth. The work shows that there is a particularly close connection between variations of the total force of atmospheric winds and small but noticeable changes in the velocity of the Earth's rotation. Other aspects of the motion and orientation of the Earth are closely related to the combination of atmospheric and oceanic influences. In particular, AER researchers have found that changes in pressure at the bottom of the ocean also contribute to changes in the velocity of the Earth's rotation. Input data for calculating the ocean angular momentum is found on the Atmospheric and Environmental Research web site.

Table 10 shows the average annual change of angular momentum of the mass of the ocean and change of the angular momentum of the ocean motion, as well as its total angular momentum from 1996 to 2014.

Fig. 20 represents the change of the average annual angular momentum of the Antarctic tectonic plate and the total angular momentum of the ocean. As it can be seen from the figure, angular momentum of the ocean is asynchronous to angular momentum of the Antarctic tectonic plate. The explanation of this phenomenon requires additional research. Deviations recorded only in 2006-2007 and 2013.

Continuation of research on other tectonic plates may allow the development of predictive models of rotational parameters of tectonic plates based on the average annual changes of the angular velocity of the Earth's rotation which is important for the establishment of new coordinate systems and the forecasting of global crustal motions.

Change of the average annual angular momentum of the ocean mass, the water motion, and the total ocean angular momentum for the period 1996-2014

\begin{tabular}{|c|c|c|c|}
\hline Years & $\begin{array}{c}\text { Change of the angular } \\
\text { momentum of the ocean } \\
\text { mass }\left(\mathrm{kg} \cdot \mathrm{m}^{2} \cdot \mathrm{rad} / \mathrm{s}\right)\end{array}$ & $\begin{array}{c}\text { Change of angular } \\
\text { momentum of the ocean } \\
\text { motion }\left(\mathrm{kg} \cdot \mathrm{m}^{2} \cdot \mathrm{rad} / \mathrm{s}\right)\end{array}$ & $\begin{array}{c}\text { Total ocean angular } \\
\text { momentum } \\
\left(\mathrm{kg} \cdot \mathrm{m}^{2} \cdot \mathrm{rad} / \mathrm{s}\right)\end{array}$ \\
\hline 1996 & 0 & 0 & 0 \\
\hline 1997 & $-9.375 \cdot 10^{22}$ & $-2.056 \cdot 10^{22}$ & $-1.143 \cdot 10^{23}$ \\
\hline 1998 & $5.901 \cdot 10^{23}$ & $-7.534 \cdot 10^{22}$ & $5.148 \cdot 10^{23}$ \\
\hline 1999 & $1.615 \cdot 10^{23}$ & $-1.582 \cdot 10^{23}$ & $3.281 \cdot 10^{21}$ \\
\hline 2000 & $-2.107 \cdot 10^{23}$ & $-2.424 \cdot 10^{23}$ & $-4.531 \cdot 10^{23}$ \\
\hline 2001 & $-7.749 \cdot 10^{22}$ & $8.073 \cdot 10^{22}$ & $3.234 \cdot 10^{21}$ \\
\hline 2002 & $-3.958 \cdot 10^{23}$ & $-7.902 \cdot 10^{22}$ & $-4.748 \cdot 10^{23}$ \\
\hline 2003 & $7.211 \cdot 10^{22}$ & $1.049 \cdot 10^{22}$ & $8.26 \cdot 10^{22}$ \\
\hline 2004 & $8.277 \cdot 10^{22}$ & $-4.485 \cdot 10^{22}$ & $3.792 \cdot 10^{22}$ \\
\hline 2005 & $1.113 \cdot 10^{22}$ & $-8.999 \cdot 10^{22}$ & $-7.886 \cdot 10^{22}$ \\
\hline 2006 & $1.598 \cdot 10^{23}$ & $-8.183 \cdot 10^{22}$ & $7.793 \cdot 10^{22}$ \\
\hline 2007 & $-4.167 \cdot 10^{23}$ & $-4.13 \cdot 10^{23}$ & $-8.297 \cdot 10^{23}$ \\
\hline 2008 & $6.919 \cdot 10^{23}$ & $3.022 \cdot 10^{23}$ & $9.94 \cdot 10^{23}$ \\
\hline 2009 & $-5.069 \cdot 10^{23}$ & $-1.001 \cdot 10^{23}$ & $-6.071 \cdot 10^{23}$ \\
\hline 2010 & $6.003 \cdot 10^{23}$ & $7.899 \cdot 10^{22}$ & $6.793 \cdot 10^{23}$ \\
\hline 2011 & $-5.397 \cdot 10^{22}$ & $-2.13 \cdot 10^{23}$ & $-2.67 \cdot 10^{23}$ \\
\hline 2012 & $-1.297 \cdot 10^{23}$ & $-1.254 \cdot 10^{23}$ & $-2.551 \cdot 10^{23}$ \\
\hline 2013 & $-1.682 \cdot 10^{23}$ & $9.918 \cdot 10^{22}$ & $-6.898 \cdot 10^{22}$ \\
\hline 2014 & $3.54 \cdot 10^{23}$ & $1.261 \cdot 10^{23}$ & $4.801 \cdot 10^{23}$ \\
\hline
\end{tabular}




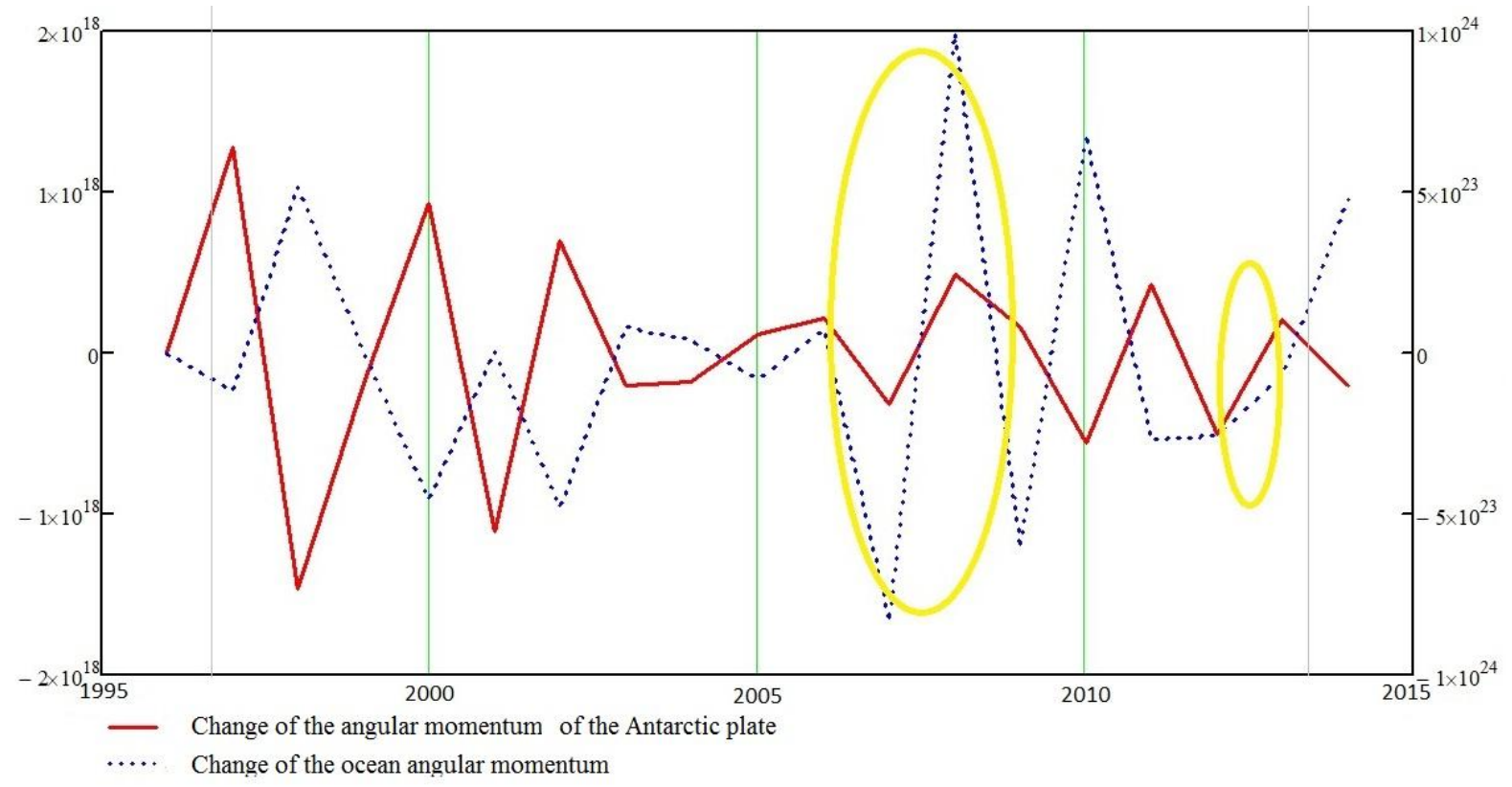

Fig. 20. Change of the average annual angular momentums of the Antarctic tectonic plate and the average annual total angular momentums the ocean

\section{Conclusions}

1) The position of the average Euler pole, angular velocity of the plate rotation and their annual changes are determined using the results of daily solutions of 28 permanent Antarctic GNSS-stations for the period 1996-2014.

2) According to the results of determining the Antarctic tectonic plate tensors of the inertia moment relative to the Euler pole and to the south pole, it is established that the inertia moment relatively to the south pole is less than the inertia moment relative to the Euler pole. This indicates that the power stresses that arise as a result of interaction with neighbouring tectonic plates have an effect on rotation of the Antarctic tectonic plate around the Euler pole. Therefore, the Euler pole is more distant from the center of gravity of the Antarctic tectonic plate, and the south pole is, on the contrary, closer to its center of gravity.

3) The change of the conditional angular momentum of the Earth and angular momentum of the Antarctic tectonic plate has an asynchronous manifestation. With increase of angular momentum of the Earth, the angular momentum of the Antarctic tectonic plate decreases and vice versa, that indicates the law of conservation of angular momentum between the body of the Earth and the Antarctic tectonic plate.

4) The change of angular momentum of the Antarctic tectonic plate and angular momentum of the atmosphere is synchronous, that allows suggesting that the mechanism of interaction of conditional angular momentum of the Earth and the atmosphere is the same as the interaction of the system the Earth the Antarctic tectonic plate.

5) Changes of angular momentums of the Antarctic tectonic plate and angular momentum of the ocean are asynchronous. Thereafter, the interaction of "the Earth - the ocean" system has the opposite interaction than the systems "the Earth - the Antarctic tectonic plate", or "the Earth - the atmosphere". An explanation of this requires additional research.

6) On the base of implemented research, it is possible to develop the prediction of models of rotational parameters of tectonic plates based on the average annual changes of the angular velocity of the Earth's rotation, which is important for the establishment of new reference systems and the forecasting of global crustal motions.

\section{References}

Altamimi, Z., Métivier, L., \& Collilieux, X. (2012). ITRF2008 plate motion model. Journal of Geophysical Research: Solid Earth, 117(B7). doi:10.1029/2011jb008930

Argus, D. F., \& Gordon, R. G. (1991). Noo-net-rotation model of current plate velocities incorporating plate motion model NUVEL-1. Geophysical research letters, 18(11), 2039-2042.

Argus, D. F., Gordon, R. G., \& Demets, C. (2011). Geologically current motion of 56 plates relative to the no-net-rotation reference frame. Geochemistry, Geophysics, Geosystems, 12(11). doi:10.1029/2011gc003751

Baranov, A., \& Morelli, A. (2013, April). The Moho depth and the inner crustal structure of the Antarctica region. In EGU General Assembly Conference Abstracts (Vol. 15).

Bowin, C. (2010). Plate tectonics conserves angular momentum. EEarth, 5(1), 1-20. doi:10.5194/ee-512010

Brosche, P., \& Sündermann, J. (1985). The Antarctic Circumpolar Current and its influence on the Earth's rotation. Deutsche Hydrografische Zeitschrift, 38(1), 1-6. 
Brosche, P., Wünsch, J., Frische, A., Sündermann, J., \& Maier-Reimer, E. (1990). The seasonal variation of the angular momentum of the oceans. Naturwissenschaften, 77(4), 185-186.

Brosche, P., Wünsch, J., Maier-Reimer, E., Segschneider, J., \& Sündermann, J. (1997). The axial angular momentum of the general circulation of the oceans. Astronomische Nachrichten, 318(3), 193-199.

Bryan, F. O. (1997). The axial angular momentum balance of a global ocean general circulation model. Dynamics of atmospheres and oceans, 25(3), 191-216.

Sottili, G., Palladino, D. M., Cuffaro, M., \& Doglioni, C. (2015). Earth's rotation variability triggers explosive eruptions in subduction zones. Earth, Planets and Space, 67(1), 208.

Celaya, M. A., Wahr, J. M., \& Bryan, F. O. (1999). Climate-driven polar motion. Journal of Geophysical Research: Solid Earth, 104(B6), 12813-12829.

Chen, J. L., Wilson, C. R., Chao, B. F., Shum, C. K., \& Tapley, B. D. (2000). Hydrological and oceanic excitations to polar motion andlength-of-day variation. Geophysical Journal International, 141(1), 149-156.

Dickey, J. O., Marcus, S. L., Johns, C. M., Hide, R., \& Thompson, S. R. (1993). The oceanic contribution to the Earth's seasonal angular momentum budget. Geophysical research letters, 20(24), 2953-2956.

Dickman, S. R. (1998). Determination of oceanic dynamic barometer corrections to atmospheric excitation of Earth rotation. Journal of Geophysical Research: Solid Earth, 103(B7), 15127-15143.

Dietrich, R., \& Rülke, A. (2008). A precise reference frame for Antarctica from SCAR GPS campaign data and some geophysical implications. In Geodetic and Geophysical Observations in Antarctica (pp. 1-10). Springer, Berlin, Heidelberg.

Dietrich, R., Dach, R., Engelhardt, G., Ihde, J., Korth, W., Kutterer, H. J., ... \& Müller, C. (2001). ITRF coordinates and plate velocities from repeated GPS campaigns in Antarctica-an analysis based on different individual solutions. Journal of Geodesy, 74(11-12), 756-766.

Dietrich, R., Rülke, A., Ihde, J., Lindner, K., Miller, H., Niemeier, W., ... \& Seeber, G. (2004). Plate kinematics and deformation status of the Antarctic Peninsula based on GPS. Global and Planetary Change, 42(1-4), 313-321.

Drewes, H. (2009). The actual plate kinematic and crustal deformation model APKIM2005 as basis for a non-rotating ITRF. In Geodetic Reference Frames (pp. 95-99). Springer, Berlin, Heidelberg. DOI:10.1007/978-3-642-00860-3_15, 2009.

Drewes, H., \& Angermann, D. (2001). The actual plate kinematic and crustal deformation model 2000 (APKIM 2000) as a geodetic reference system. In IAG 2001 Scientific Assembly, Budapest, Hungary.

Drewes, H. (1998). Combination of VLBI, SLR and GPS determined station velocities for actual plate kinematic and crustal deformation models. In Geodesy on the Move (pp. 377-382). Springer, Berlin, Heidelberg.

Eubanks, T. M. (1993). Interactions between the atmosphere, oceans and crust: Possible oceanic signals in Earth rotation. Advances in Space Research, 13(11), 291-300.

Frische, A., \& Sündermann, J. (1990). The seasonal angular momentum of the thermohaline ocean circulation. In Earth's Rotation From Eons to Days (pp. 108-126). Springer, Berlin, Heidelberg.

Furuya, M., \& Hamano, Y. (1998). Effect of the Pacific Ocean on the Earth's seasonal wobble inferred from National Center for Environmental Prediction ocean analysis data. Journal of Geophysical Research: Solid Earth, 103(B5), 10131-10140.

Fylatj'ev V. P. (2007). The influence of rotational effects on the tectonics of the planet (on the example of the transition zone from the Asian continent to the Pacific Ocean). Rotational processes in Geology and Physics. Moscow., 341360 (in Russian).

Khain, V. E., \& A. I. Poletayev. (2007). Rotation tectonics of the Earth. Science in Russia, (6), 1421 (in Russian).

National Geophysical Data Center. (2006, July 26). ETOPO5 Data and Documentation | ngdc. noaa.gov. Retrieved from https://www. ngdc.noaa.gov/mgg/global/etopo5.HTML

Pandul, Y. (2017). Geodetic astronomy applied to the solution of engineering and geodesic problems. Litres.

Project Overview. (n.d.). Retrieved from http://ggosatm.hg.tuwien.ac.at/

Sottili, G., Palladino, D. M., Cuffaro, M., \& Doglioni, C. (2015). Earth's rotation variability triggers explosive eruptions in subduction zones. Earth, Planets and Space, 67(1), 208. https://doi.org/ $10.1186 / \mathrm{s} 40623-015-0375-\mathrm{Z}$

Seitz, F., \& Schmidt, M. (2005). Atmospheric and oceanic contributions to Chandler wobble excitation determined by wavelet filtering. Journal of Geophysical Research: Solid Earth,110(B11). doi:10.1029/2005jb003826

Navigation and service. (n.d.). Retrieved from https://www.iers.org/IERS/EN/Home/home_node. html

Johnson, T. J., Wilson, C. R., \& Chao, B. F. (1999). Oceanic angular momentum variability estimated from the Parallel Ocean Climate Model, 19881998. Journal of Geophysical Research: Solid Earth,104(B11), 25183-25195. doi:10.1029/1999jb900231

Khain, V. E. (2010). Constructing a truly global model of Earth's dynamics: basic principles. Russian Geology and Geophysics, 51(6), 587-591. 
Tretjak K. R., Alj-Alusi F. K. F. About relationship of uneven of the Earth rotational movement and Antarctic tectonic plate. Ukrainian Antarctic Journal, (14), 43-57 (in Ukrainian).

Tretyak, K., Forat, A., \& Holubinka, Y. (2017). Investigation of Changes of the Kinematic Parameters of Antarctic Tectonic Plate Using Data Observations of Permanent GNSS Stations. Reports on Geodesy and Geoinformatics, 103(1). doi:10.1515/rgg-2017-0010

Kane, M. F. (1972). Rotational Inerfia of Continents: A Proposed Link between Polar Wandering and Plate Tectonics. Science, 175(4028), 1355-1357. doi:10.1126/science.175.4028.1355

Nastula, J., \& Ponte, R. M. (1999). Further evidence for oceanic excitation of polar motion. Geophysical Journal International, 139(1), 123130. doi:10.1046/j.1365-246x.1999.00930.x

Link to our Data Products Page:. (n.d.). Retrieved from http://geodesy.unr.edu/

Ponte, R. M., \& Gutzler, D. S. (1991). The MaddenJulian oscillation and the angular momentum balance in a barotropic ocean model. Journal of Geophysical Research: Oceans, 96(C1), 835-842. doi:10.1029/90jc02277

Ponte, R. M., \& Stammer, D. (2000). Global and regional axial ocean angular momentum signals and length-of-day variations (1985-1996). Journal of Geophysical Research: Oceans, 105(C7), 1716117171. doi:10.1029/1999jc000157

Ponte, R. M., \& Stammer, D. (1999). Role of ocean currents and bottom pressure variability on seasonal polar motion. Journal of Geophysical Research: Oceans, 104(C10), 23393-23409. doi:10.1029/1999jc900222

Ponte, R. M., \& Rosen, R. D. (1994). Oceanic angular momentum and torques in a general circulation model. Journal of physical oceanography, 24(9), 1966-1977.

Ponte, R. M. (1990). Barotropic motions and the exchange of angular momentum between the oceans and solid Earth. Journal of Geophysical Research, 95(C7), 11369. doi:10.1029/jc095ic07p11369
Ponte, R. M., Stammer, D., \& Marshall, J. (1998). Oceanic signals in observed motions of the Earths pole of rotation. Nature, 391(6666), 476-479. doi:10.1038/35126.

Ponte, R. M. (1997). Oceanic excitation of daily to seasonal signals in Earth rotation: Results from a constant-density numerical model. Geophysical Journal International, 130(2), 469-474. doi:10.1111/j.1365-246x.1997.tb05662.x

Schettino, A. (1999). Computational methods for calculating geometric parameters of tectonic plates. Computers \& Geosciences, 25(8), 897907. doi:10.1016/s0098-3004(99)00054-0

Scripps Orbit and Permanent Array Center (SOPAC). (n.d.). Retrieved from http://sopac.ucsd.edu/

Sella, G. F., Dixon, T. H., \& Mao, A. (2002). REVEL: A model for Recent plate velocities from space geodesy. Journal of Geophysical Research: Solid Earth, 107(B4). doi:10.1029/2000jb000033

Jin, S., \& Zhu, W. (2004). A revision of the parameters of the NNR-NUVEL-1A plate velocity model. Journal of Geodynamics, 38(1), 85-92. doi:10.1016/j.jog.2004.03.004

Tretyak, K. R., \& Vovk, A. I. (2016). Differentation of the rotational movements of the european continents Earth crust. Acta Geodynamica et Geomaterialia, 13(1), 181.

Vikulin, A. (2015). Geodynamics as wave dynamics of the medium composed of rotating blocks. Geodynamics \& Tectono-physics, 6(3), 345-364. doi:10.5800/gt-2015-6-3-0185

Vikulin, A. V., Makhmudov, Kh. F., Ivanchin, A. G., Gerus, A. I., \& Dolgaya, A. A. (2016). On the wave and reid properties of the Earth's crust. Solid State Physics, 58 (3), 547-557.

Jiang, W., E, D., Zhan, B., \& Liu, Y. (2009). New Model of Antarctic Plate Motion and Its Analysis. Chinese Journal of Geophysics, 52(1), 23-32. i:10.1002 /cjg2. 1323

Wu, X., Ray, J., \& Dam, T. V. (2012). Geocenter motion and its geodetic and geophysical implications. Journal of Geodynamics, 58, 44-61. doi:10.1016/j.jog.2012.01.007

\section{К. ТРЕТЯК ${ }^{1}$, Ф. К. АЛЬ-АЛУСІ ${ }^{2}$ Л. БАБІЙ ${ }^{3}$}

\footnotetext{
${ }^{1}$ Кафедра вищої геодезії та астрономії, Національний університет “Львівська політехніка”, вул. С. Бандери, 12 , Львів, Україна, 79013

${ }^{2}$ Навчально-наукова лабораторія “Опрацювання супутникових вимірів", Національний університет “Львівська політехніка", вул. С. Бандери, 12, Львів, Україна, 79013

${ }^{3}$ Кафедра фотограмметрії та геоінформатики, Національний університет “Львівська політехніка”, вул. С. Бандери, 12, Львів, Україна, 79013
}

\section{ДОСЛІДЖЕННЯ ВЗАСМОЗВ' ЯЗКУ МІЖ ЗМІНАМИ ТА ПЕРЕРОЗПОДІЛОМ МОМЕНТУ ІМПУЛЬСУ ЗЕМЛІ, АНТАРКТИЧНОЇ ТЕКТОНІЧНОЇ ПЛИТИ, АТМОСФЕРИ ТА ОКЕАНУ}

Мета. Метою цієї роботи $є$ опрацювання результатів довготривалих ГНСС-спостережень на перманентних станціях, розташованих на території Антарктичної тектонічної плити; визначення зміни їі ротаційних параметрів та моменту імпульсу, обчислення зміни моменту імпульсу Землі , океанічних та атмосферних мас і встановлення взаємозв'язку між цими параметрами. Методика. У роботі 
представлено удосконалений алгоритм визначення параметрів полюсу Ейлера і кутової швидкості обертання тектонічної плити з урахуванням безперервності та нерівномірності часових серій щоденних розв'язків просторового розташування перманентних ГНСС-станцій. Результати. За результатами щоденних розв'язків 28 перманентних ГНСС-станцій Антарктиди за період (1996-2014 рр.) визначено положення середнього полюсу Ейлера, кутової швидкості обертання плити та їхні щорічні зміни. Визначено щорічні параметри тензора інерції та моменту імпульсу Антарктичної тектонічної плити. Обчислено за даними служби обертання Землі та геофізичних спостережень щорічні зміни моменту імпульсу Землі та тензори моменту інерції та величини моменту імпульсу океанічних та атмосферних мас за період (1996-2014 р.). Наукова новизна. Встановлено, що практично протягом усього періоду спостережень збільшенню моменту імпульсу Антарктичної тектонічної плити відповідає зменшення моменту імпульсу Землі та атмосфери, що свідчить про збереження моменту імпульсу. Збільшенню моменту імпульсу Антарктичної тектонічної плити відповідає збільшення моменту імпульсу океану. Пояснення цього взаємозв’ язку вимагає додаткових досліджень.

Ключові слова: Антарктична плита; момент імпульсу; тензор інерції; кутова швидкість; полюс Ейлера; ГНСС-станції.

\section{К. ТРЕТЯК ${ }^{1}$, Ф. К. Ф. АЛЬ-АЛУСИ², Л. БАБИЙ ${ }^{3}$}

${ }^{1}$ Кафедра высшей геодезии и астрономии, Национальный университет “Львовская политехника”, ул. Карпинского, 6, Львов,Украина, 79013

2 Учебно-научная лаборатория “Обработки спутниковых измерений”, Национальный университет “Львовская политехника”, ул. С. Бандеры, 12, Украина, 79013

3 Кафедра фотограмметрии и геоинформатики, Национальный университет “Львовская политехника", ул. Карпинского, 6, Львов, Украина, 79013

\section{ИССЛЕДОВАНИЕ ВЗАИМОСВЯЗИ МЕЖДУ ИЗМЕНЕНИЯМИ \\ И ПЕРЕРАСПРЕДЕЛЕНИЕМ МОМЕНТА ИМПУЛЬСА ЗЕМЛИ, АНТАРКТИЧЕСКОЙ ТЕКТОНИЧЕСКОЙ ПЛИТЫ, АТМОСФЕРЫ И ОКЕАНА}

Цель. Целью данной работы является обработка результатов длительных ГНСС-наблюдений на перманентных станциях, расположенных на территории Антарктической тектонической плиты; определения изменения ее ротационных параметров и момента импульса, вычисления изменения момента импульса Земли, океанических и атмосферных масс и установление взаимосвязи между этими параметрами. Методика. В работе представлены усовершенствованный алгоритм определения параметров полюса Эйлера и угловой скорости вращения тектонической плиты с учетом непрерывности и неравномерности временных серий ежедневных решений пространственного расположения перманентных ГНСС-станций. Результаты. По результатам ежедневных решений 28 перманентных ГНСС-станций Антарктиды за период (1996-2014 гг.), определено положение среднего полюса Эйлера и угловой скорости вращения плиты и их ежегодные изменения. Определены ежегодные параметры тензора инерции и момента импульса Антарктической тектонической плиты. Вычислено по данным службы вращения Земли и геофизических наблюдений ежегодные изменения момента импульса Земли и тензоры момента инерции и величины момента импульса океанических и атмосферных масс за период (1996-2014 гг.). Научная новизна. Установлено, что практически в течение всего периода наблюдений увеличению момента импульса Антарктической тектонической плиты соответствует уменьшение момента импульса Земли и атмосферы, это свидетельствует о сохранении момента импульса. Увеличению момента импульса Антарктической тектонической плиты соответствует увеличение момента импульса океана. Объяснение этого взаимосвязи требует дополнительных исследований.

Ключевые слова: Антарктическая плита; момент импульса; тензор инерции; угловая скорость; полюс Эйлера.

Received 05.03.2018 